Postprint

\title{
Supply Risks Associated with CdTe and CIGS Thin-Film Photovoltaics
}

\author{
Christoph Helbig ${ }^{*}$, , Alex M. Bradshaw ${ }^{b, c}$, Christoph Kolotzek $^{a}$, Andrea Thorenz $^{a}$, Axel Tuma ${ }^{a}$ \\ *Address correspondence to: christoph.helbig@wiwi.uni-augsburg.de \\ a : Resource Lab, Institute of Materials Resource Management, University of Augsburg, \\ Universitaetsstr. 16, 86159 Augsburg, Germany \\ b: Max Planck Institute for Plasma Physics, Boltzmannstraße 2, 85748 Garching, Germany \\ c: Fritz Haber Institute, Faradayweg 4-6, 14195 Berlin, Germany
}

Published in: Applied Energy 178 (2016), 422-433. https://doi.org/10.1016/j.apenergy.2016.06.102

\begin{abstract}
As a result of the global warming potential of fossil fuels there has been a rapid growth in the installation of photovoltaic generating capacity in the last decade. While this market is dominated by crystalline silicon, thin-film photovoltaics are still expected to make a substantial contribution to global electricity supply in future, due both to lower production costs and to recent increases in conversion efficiency. At present, cadmium telluride ( $\mathrm{CdTe}$ ) and copper-indium-gallium diselenide $\left(\mathrm{Culn}_{\mathrm{x}} \mathrm{Ga}_{1-\mathrm{x}} \mathrm{Se}_{2}\right.$ ) seem to be the most promising materials and currently have a share of $\approx 9 \%$ of the photovoltaic market. An expected stronger market penetration by these thin-film technologies raises the question as to the supply risks associated with the constituent elements. Against this background, we report here a semi-quantitative, relative assessment of mid- to long-term supply risk associated with the elements $\mathrm{Cd}, \mathrm{Te}, \mathrm{Cu}, \mathrm{In}, \mathrm{Ga}$, Se and Mo. In this approach, the supply risk is measured using 11 indicators in the four categories "Risk of Supply Reduction", "Risk of Demand Increase", "Concentration Risk" and "Political Risk". In a second step, the single indicator values, which are derived from publicly accessible databases, are weighted relative to each other specifically for the case of thin film photovoltaics. For this purpose, a survey among colleagues and an Analytic Hierarchy Process (AHP) approach are used, in order to obtain a relative, element-specific value for the supply risk. The aggregation of these elemental values (based on mass share, cost share, etc.) gives an overall value for each material. Both elemental and "technology material" supply risk scores are subject to an uncertainty analysis using Monte Carlo simulation. CdTe shows slightly lower supply risk values for all aggregation options.
\end{abstract}

\section{Keywords}

supply risk; thin-film photovoltaics; cadmium telluride; copper-indium-gallium diselenide; analytic hierarchy process; monte carlo simulation 


\section{Introduction}

The advantages of photovoltaic (PV) solar energy are direct electricity production, simple mechanical construction and, most importantly, a very substantial reduction in greenhouse gas emissions compared to fossil fuels [1-3]. As a result, there has recently been an astonishing growth in photovoltaic capacity worldwide, despite the serious problem of intermittency and the apparent reluctance to address the resulting storage challenges. In fact, the annual growth in globally installed photovoltaic capacity has been around $40 \%$ per annum in recent years, resulting in a cumulative total of $177 \mathrm{GWp}$ in 2014 [4], corresponding to a contribution to global electricity supply (in terms of energy) of about $190 \mathrm{TWh}$, or 1\% [5]. This strong market growth - aided in many countries by subsidies and generous feed-in tariffs - has been accompanied by substantial price decreases in recent years. The market for photovoltaic modules is currently dominated by crystalline silicon technology, in the form of single crystal or polycrystalline wafers. Although the market share of thinfilm photovoltaics, consisting mainly of cadmium telluride (CdTe) and copper-indium-gallium diselenide, or CIGS (CulnxGa1-xSe2) has recently fallen, there is reason to believe (Section 2) that these technologies will soon be able to position themselves more strongly in the market.

If thin-film photovoltaics were indeed to make a substantial contribution to global electricity supply later in this century, and - a second assumption - if CdTe and CIGS modules were to dominate this market, then the question arises as to the mid- to long-term supply risks associated with the constituent elements of these two materials. Supply risks describe the possible lack of availability of minerals and elements; they can be assessed, at least in a qualitative or semi-quantitative way. For elements, for which it is perceived that there could be a supply risk problem in coming years, the term "critical" is often used [6-9]. The debate concerning the availability of minerals and their constituent elements has been going on for over half a century [10-14]. Initially, it focused on the (limited) quantities contained in the mineral deposits of the Earth's crust and was driven by the fear that there would not be sufficient amounts to cover the requirements of a technologically advanced society with a growing population. Thus, Goeller and Weinberg, for example, warned about the impending mineral depletion problem and how it could perhaps be overcome through recycling and substitution (and a considerable amount of energy!) [11]. They were contradicted in a vigorous rebuttal by Simon, a well-known "cornucopian" [12]. The last two decades have actually seen a massive increase in the use of many "rare" metals for a variety of new, high-tech applications. (The term "rare" is often used when the elemental concentration in the continental crust is lower than about $0.1 \%$ [15].) This in turn has led to considerable interest in supply risk assessments [7,16-23]. As noted above, early studies concentrated on the possibility of a serious depletion of mineral stocks in the Earth's crust. There are usually two "indicators" in such assessments that are associated with the extent of the known reserves as well as with the known and putative resources of a particular element. In recent years, further indicators have been formulated to account for the many other factors that can contribute to the supply risk. Extraction as a by-product during the mining of another metal is, for example, a further supply risk, since availability depends on the technology and profitability of extraction of the "parent" metal [24]. Many by-product metals are also rare and/or characterized by a lack of economically viable deposits; they often lack recycling potential, which is another supply risk aspect $[25,26]$. Other indicators cover factors such as concentration risk when supply is in the hands of only a few companies and/or countries, possible future demand for other technological applications, and political risks such as instability and governance standards in producing countries. From the numerous studies of supply risk for raw materials published in the last 
ten years Achzet and Helbig [19] have recently identified as many as 20 indicators used by various authors.

How can supply risks be assessed using such indicators? A study published by the EU Commission is perhaps a good example [7]. It uses a so-called risk assessment matrix, based on the two composite indicators "supply risk" (consisting of various different supply risk indicators) and "economic importance", and sets threshold values for each. Materials exceeding both of these values are designated as being critical. Forty-one non-fuel metals and minerals were investigated, of which 14 were designated as critical. In a second study [27] some years later using the same indicators and, most importantly, the same thresholds, the list was modified. Several recent studies have been concerned specifically with energy-related materials, i.e. materials that are required for the generation, transmission, storage and utilization of energy, in particular those that will be needed for the transformation to a low-carbon energy economy [20,21,28-40].

Several authors have recently considered thin-film CdTe and CIGS photovoltaics from the point of view of technological relevance [3], environmental impacts [41], demand- and supply-side economics or costs [42-47], and materials supply risk [20,48-53]. Graedel and Nuss [50] have made a multielement, multi-indicator study of supply risk for CdTe and CIGS absorber materials based on their extensive "criticality" data bank of the elements [18,54,55]. Goe and Gaustad [20] have also studied photovoltaic materials using mainly U.S.-based data and several indicators but, like Graedel and Nuss, do not broach the problem of aggregation, i.e. the determination of the relative supply risks associated with the two compounds. In the present paper, we first determine the supply risk associated with the two elements, $\mathrm{Cd}$ and $\mathrm{Te}$, as well as the supply risk associated with the five elements $\mathrm{Cu}, \mathrm{In}, \mathrm{Ga}$, Se and Mo. Our philosophy is, however, somewhat different than that of the two previous papers, in that our eleven indicators are chosen and categorized (as in a previous study of some of the authors [56]) and weighted (using a questionnaire answered by colleagues in both academia and industry) for the specific case of thin film photovoltaics. Moreover, in order to assess relative supply risks for the two compounds, various aggregation procedures for the supply risks associated with the individual elements, are explored and tested. Whilst acknowledging the importance of environmental and sustainability factors, we emphasize that our composite indicators are intentionally based on supply risk only. Despite these differences in methodology, the present investigation can be seen as a further development of the Graedel and Nuss approach. We demonstrate not only the importance of a multi-indicator analysis that is as comprehensive as possible, but also of a product-oriented weighting of the indicators. Moreover, we show that the concept of supply risk on a comparative basis can be applied at the product, or technology, level, if thought is given to the aggregation problem.

The structure of the paper is as follows. In the next section we briefly describe the CdTe and CIGS technologies and report latest module efficiency data. Section 3 describes the supply risk evaluation model in detail. Section 4 shows the application of the technique first on the level of the elements themselves and then for the two technologies. The article concludes (Section 5) with a discussion and a summary.

\section{Thin-film photovoltaics}

By way of illustration, typical CdTe and CIGS solar cells are shown schematically in cross-section in Figure 1 (after Ref. [32,57]). Note that only those (functional) layers are shown which are essential for the operation of the cell. The absorber layers have typically a thickness of 1-3 micrometer. A 
typical thin-film photovoltaic module of $\approx 1 \mathrm{~m}^{2}$ may contain up to 80 cells which are appropriately interconnected. The physics background, technical details and future R\&D directions are described in the literature $[3,58]$. For present purposes it suffices to summarize briefly some general aspects, concentrating on the market situation and performance data of the last few years.

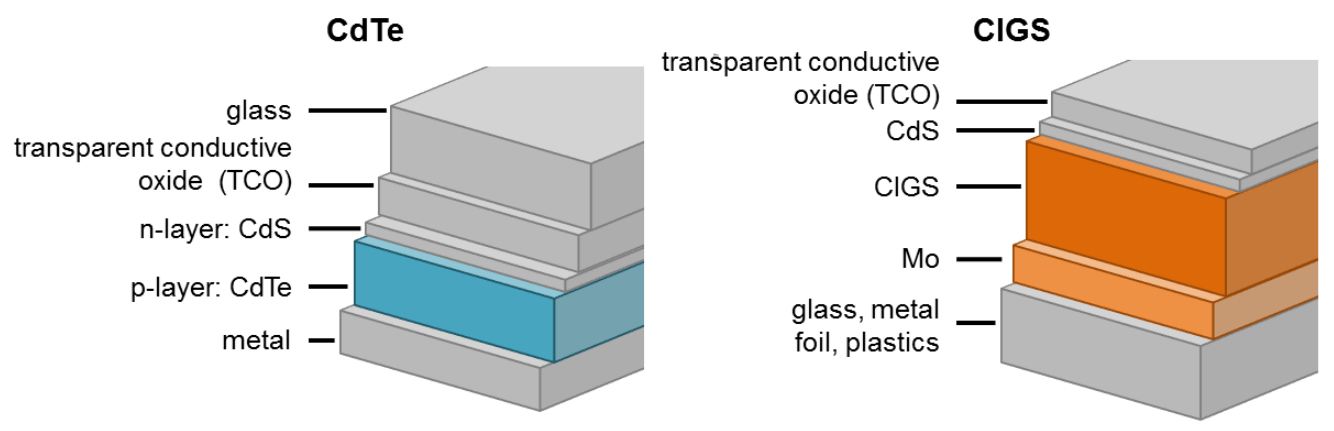

Figure 1: Layers of CdTe and CIGS photovoltaic cells. Only the functional layers which are essential for each technology are depicted.

In Table 1 the first row shows the figures for the total global production of photovoltaic modules (sum of thin film and crystalline silicon) in GWp for the five years up to, and including 2014. There may be a slight inconsistency in the data, because the figures for the first three years actually refer to installed capacity, whereas those for 2013 and 2014 refer to production [59]. The strong growth rate of about $40 \%$ per year noted in the Introduction is immediately apparent. The second, third and fourth rows give the total contribution of thin-film modules as well as the contributions of CdTe and CIGS modules, respectively. We note that in a rapidly expanding photovoltaic market the production figures for thin-film modules have remained more or less constant during this period, but that their market share has fallen to 9\%; crystalline silicon now has over $90 \%$. Also shown are the highest module efficiency data from Green et al. [60] for CdTe and CIGS, in the fourth and sixth rows, respectively. For inclusion in the data tables, the efficiency determination must be made under standard conditions in a recognized testing laboratory. There are some interesting general points to note in connection with Table 1. Firstly, it should be recalled that the highest module efficiency is understandably always a few percent lower than the highest (research) cell efficiency, which is also a frequently quoted, if less meaningful parameter. Secondly, we note the very strong increase in module efficiency for CdTe in the last few years, namely, from $10.9 \%$ to $18.6 \%$. The latter is a value comparable to that for polycrystalline silicon (18.5\%), although still lower than that for single crystal silicon (22.4\%). The highest efficiency measured for thin-film silicon, actually a-Si/nc-Si, i.e. amorphous/nanocrystalline, is $12.3 \%$. Thirdly, the increase in efficiency for CIGS in recent years has not been so dramatic, although it should be pointed out that a value of $17.5 \%$ was reported in 2014 for a small CIGS Cd-free module $\left(\approx 800 \mathrm{~cm}^{2}\right)$ from Solar Frontier [60]. This compares to the "standard value" in Table 1 of $15.7 \%$ for a large module, which has been constant for some years.

Other technologies involving organic compounds, polymers or dye-sensitized nano-structured films have so far not played a major role commercially, although some are available as modules. It remains to be seen whether the spectacularly improving performance of perovskite research cells [61] will lead to commercially viable modules, for which the degradation problem has been solved. It should also be noted that there are numbers to show that the fabrication costs for thin-film modules are marginally lower than those for crystalline silicon modules [59]. Moreover, the energy payback time for thin-film modules (particularly CdTe) is substantially lower than that for crystalline silicon 
modules [62]. In summary, we conclude from the present discussion that thin-film modules are in a position to establish themselves more strongly on the market in coming years.

Table 1: Module production and best module efficiency 2010 - 2015. Production/installed capacity data are from the Fraunhofer Institute for Solar Energy Systems [59]; the data for 2010 are extrapolated from plots for

2011. The first row "global module production" corresponds to the sum of crystalline silicon and thin-film modules. The best module efficiency data are from Green et al. [60] and references to earlier papers therein.

The one exception to the latter is the $\mathbf{2 0 1 5}$ value for CdTe modules, which is taken from a First Solar press release [63] reporting a value of $18.6 \%$, as measured by a recognized testing laboratory. nya: not yet available.

\begin{tabular}{lllllll} 
& 2010 & 2011 & 2012 & 2013 & 2014 & 2015 \\
\hline Global module production, GWp & 17.5 & 22.8 & $\approx 30$ & $\approx 35$ & $\approx 48$ & nya \\
\hline Thin-film module production, GWp & 2.3 & 3.2 & 4.3 & 3.2 & 4.4 & nya \\
\hline CdTe module production, GWp & 1.4 & 1.9 & 1.9 & 1.8 & 1.9 & nya \\
\hline CdTe best module efficiency, \% & 10.9 & 12.8 & 15.3 & 16.1 & 17.5 & 18.6 \\
\hline CIGS module production, GWp & 0.3 & 0.7 & 1.05 & 0.7 & 1.7 & nya \\
\hline CIGS best module efficiency, \% & 13.5 & 15.7 & 15.7 & 15.7 & 15.7 & 15.7
\end{tabular}

Several authors have already looked at aspects of the supply risk problem in connection with photovoltaic materials, which is the central question of the present paper. Jean et al. [3] have estimated the quantities of those elements that would be required for generating a substantial proportion of global electricity using photovoltaics (corresponding to $25 \mathrm{TWp}$ installed capacity in their scenario) by the year 2050. In an interesting discussion they emphasize the general constraints associated with the large-scale use of by-product elements (As, Ge, Cd, Se, In, Ga, Te), as also encountered in the case of CdTe and CIGS technologies. They point out that thin-film PV requirements could be up to 1500 higher than current annual production for some metals and that relative crustal abundances can still provide a rough guide to future accessibility. Moreover, according to the assessment of Jean et al, the host metals considered ( $\mathrm{Si}, \mathrm{Ag}, \mathrm{Cu}, \mathrm{S}, \mathrm{Zn}, \mathrm{Pb}, \mathrm{Sn}$ ) are far less subject to constraints [3]. Kavlak et al. [47] go into greater detail on this point, showing that the increase in production of $\mathrm{In}, \mathrm{Ga}, \mathrm{Se}, \mathrm{Cd}$ and Te required to match global PV deployment targets (e.g., reaching $8 \%$ of global electricity generation by 2030 ) would vastly exceed historically observed metal production growth rates. In particular, global tellurium production would need to grow by $23 \%$ per year, in contrast to an historical annual production rate for altogether 32 metals of only $9 \%$ per year. The required silicon production growth rate (2.5\% per year) would be comparable with data from the recent past. In addition, the crustal abundance of silicon is many orders of magnitude higher than that of Te, Se, In etc. In a similar study Elshkaki and Graedel [46] point out that in such a situation, a strong increase in demand for a PV-relevant by-product metal could lead to overproduction of its host metal (gold, silver, zinc, copper or aluminum) and other accompanying metals (e.g., arsenic). In practice, given the small contribution normally made by such by-product metals to the profitability of a refining process, this is perhaps unlikely. The studies mentioned so far, as well as several others $[42,48,53]$, have concentrated on the extent of reserves and resources of the rare metals concerned. In a study similar to the present one, Graedel and Nuss [50] have recently applied several supply risk indicators to the problem, using their methodology for the individual elements [18]. We return to this paper in the discussion.

Two life cycle-based assessments of thin-film photovoltaics have treated further aspects. Marwede and Reller [44] have demonstrated how material efficiency measures in the life cycle of a PV module 
can reduce the requirements for the metals concerned and thus the material costs. Their analysis shows how higher resource efficiency and increased recycling efforts can lead to drastic reductions, for example, by a factor four, in resource consumption. For CIGS, they observed greater efficiency improvements, and therefore a higher cost reduction potential, than for CdTe. Bergesen et al. [41] have compared thin-film photovoltaic electricity generation with the 2010 United States grid electricity mix with respect not only to resource aspects, but also to environmental and health impacts along the life cycle. CdTe modules show lower impacts compared to CIGS with respect to climate change impact, carcinogens and metal depletion. This preference for $\mathrm{CdTe}$ also remains when recycling, efficiency and dematerialization improvements projected for 2030 are taken into account.

\section{Methodology}

In the following we describe an evaluation model to assess technological supply risk [56]. It has been specifically adapted for the comparison of the two photovoltaic technologies based on CdTe (elements $\mathrm{Cd}$ and Te) and $\mathrm{CIGS}$ (elements $\mathrm{Cu}$, In, Ga, Se and Mo). We do not take into account the much larger amount of copper used for interconnects on the modules and for wiring up the modules themselves. Molybdenum is an essential substrate material for high performance CIGS cells, due to its relative stability at the processing temperature, resistance to alloying with $\mathrm{Cu}$ and $\mathrm{In}$, and its low contact resistance to the CIGS layer [64,65]. (Various different solutions, have been, and are used for CdTe $[66,67]) . M o$ is therefore included in the present analysis for CIGS. The model calculates the relative supply risk using technical and market data for each element and combines these to assess the technological supply risk associated with the product, in this case the solar cell or module.

As described above, various indicators can be used for the semi-quantitative assessment of the supply risk. Indicators express the likelihood of supply disruption. In this context, the specific contribution of Graedel et al. towards raising awareness for the topic of "critical" raw materials and their efforts to develop a method of supply risk evaluation should be expressly mentioned $[9,18,68]$. The selection and categorization of indicators in the present article is a synthesis of previous supply risk assessments in the critical raw materials context $[19,56]$. The indicators used in the present study are displayed in Figure 2. In total, four general risk criteria are considered, corresponding to four different supply disruption scenarios: risk of supply reduction, risk of demand increase, concentration risk and political risk. In the following, we consider the indicators in each category. They are also listed in Table S1 of the Supplementary Material, where the method of calculation and the appropriate references to previous work are summarized in each case.

Supply reduction could in principle occur due to dwindling reserves and resources [13]. The term "reserves" gives an estimate of the amount of natural stocks for which extraction is technically feasible and economically viable at the present time [69]. The term "resources" refers to the total amount of natural stocks for which extraction is potentially feasible; further sub-classifications of "resources" are possible [69]. We apply the two indicators by calculating the ratio between the amount of reserves/resources and annual primary production, usually called "depletion time" or "static reach", both giving a measure of the market pressure for further mineral prospecting and subsequent mining activity. A potential, but perhaps only perceived, scarcity due to dwindling reserves/resources can be partially compensated by secondary production, which is the reason why the end-of-life (EoL) recycling rate is used as a third indicator in this risk category [70].

Secondly, there is the risk of the supply of a particular metal being unable to keep up with a (sudden) increase in demand, particularly for by-product metals, which are only extracted when a corresponding host metal is mined. Although mining of the by-product would not be profitable on its 
own, the status of a metal as a by-product is not a supply reduction risk. Rather, it may limit the opportunities to increase mining production, particularly at short notice, and therefore belongs in our view in the demand-centered risk category $[24,71]$. The expectation of future increases in demand for a particular metal from other technologies is also considered as a risk factor in this category. Angerer et al. [72] have, for example, reviewed possible future demand in this respect, which is a challenging task and accompanied by potentially serious forecast errors. "Substitutability" of metals [27] (possibly in different design stages of a product [73]), is, on the other hand, a riskreducing factor in this category and gives a measure of the ease of shift in demand from one metal to another. It has been estimated, e.g. by Graedel et al. [74], in a semi-quantitative way. Each commodity is considered based on the functionality and price of the best possible, readily available substitute material for each of the main applications of an element, weighted by the percentage amount (tonnage) required for that application. It is noteworthy that future technology demand and substitutability are indicators that are frequently used as indicators both in "supply risk" and "vulnerability" assessments, but each with a somewhat different definition [75].

The third risk category is the possibility of market failure due to a high market concentration, measured using the Herfindahl-Hirschman Index ( $\mathrm{HHI})$, which is the sum over the squares of the production shares. On the national level, this indicator takes into account the annual country-specific metal production figures (mining or refining). On the corporate level, the indicator uses production figures of the producing companies. Both indicators attempt to put on a more quantitative basis those aspects of monopolistic or oligopolistic market situations that are linked to low levels of competition, potential strategic misuse and higher price levels [76].

The fourth category political risk is a measure of the potential disruption of commodity markets due to political issues and contains three indicators. These breakdowns in supply can occur due to instability in producing countries, estimated by the Worldwide Governance Indicator (WGI) "Political stability and absence of violence/terrorism" as published by the World Bank $[77,78]$. They can also occur due to increasingly strict mining regulation in producing countries; this can be estimated by the Policy Perception Index (PPI) of the Fraser Institute [79]. The third political risk indicator is the possibility of increasingly strict environmental regulation in producing countries, estimated by the Human Development Index (HDI) in these producing countries [80]. These three political indicators are reported on country-level and are aggregated at the elemental level by a weighted average based on each country's production tonnage.

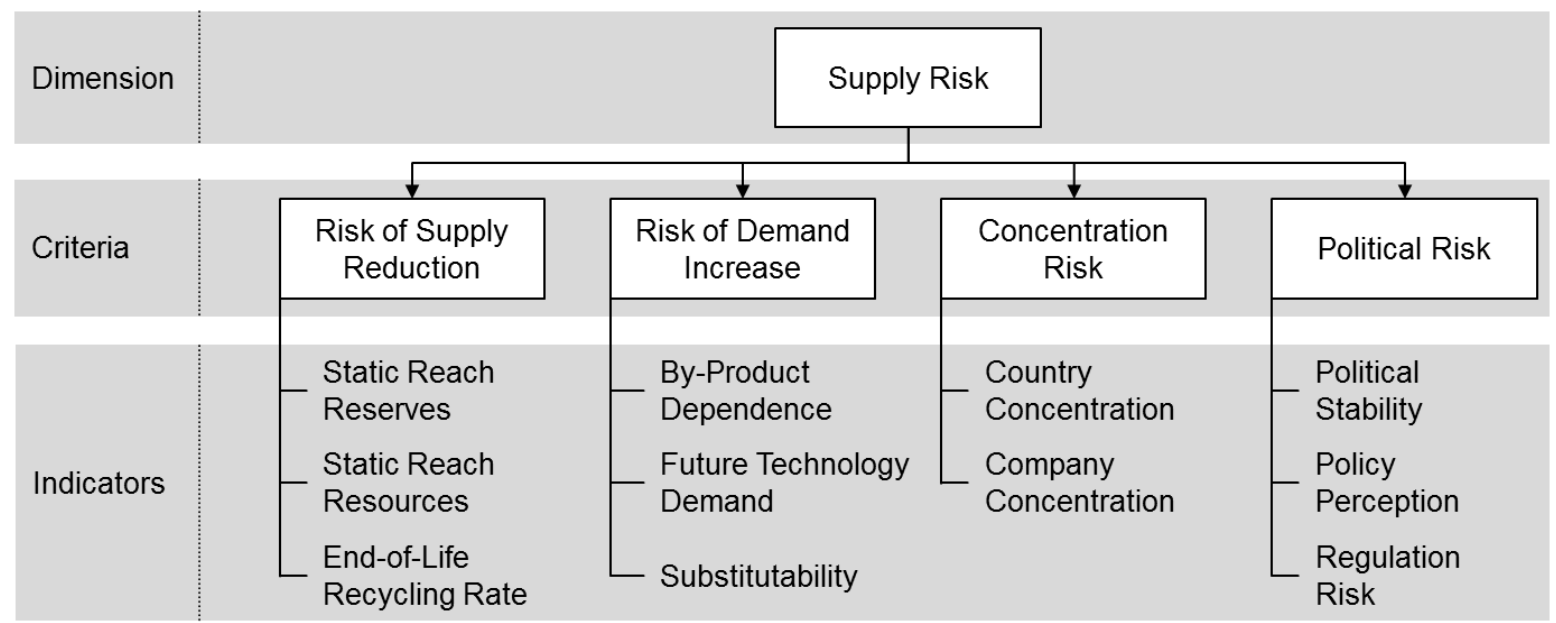

Figure 2: Supply risk criteria and indicators used for the supply risk assessment. After [56], modified. [1.5column fitting image] 
The next stage in our methodology is a normalization of the indicator scores to a common scale in order to compare these eleven supply risk indicators. We use a scale from 0 to 100 , whereby lower values correspond to lower supply risk and are thus preferred. This corresponds closely to the approach of Graedel et al. [18]. For the case of conversion from non-linear functions, the normalization procedures are taken from the literature and listed in the Supplementary Material (Tables S1, S2) $[18,81]$. In order to determine the weighting of all eleven supply risk indicators for the specific case of thin-film photovoltaics, we depart from the procedure in previous work: Ten international experts (from basic and applied research, industry and government labs) were asked to participate in an Analytic Hierarchy Process (AHP) [82]. AHP is a well-established method for solving multi-criteria decision problems based on pairwise comparisons of evaluation criteria. It is limited by the need for a low number of indicators in each category (seven is normally given as the limit) and the possibility of inconsistency in the completion of the questionnaire (our results however pass the consistency tests). The experts were asked to assess the relative importance of each indicator for the supply risk associated with each of the elements concerned using a text-based questionnaire. The first task was to weight the four general risk criteria and then to weight the indicators within each risk criterion. The AHP questionnaire is shown in the Supplementary Material (Figures S1 to S3). The supply risk scores for each of the seven elements are calculated as a weighted average of the eleven normalized risk indicator scores (0 to 100) using the weightings calculated from the AHP. In a subsequent sensitivity analysis these AHP supply risk scores for each element are compared with those obtained with two alternative weightings. In the so-called "group weighting" all four risk categories are weighted equally and then each indicator in that category is given equal weighting. In "equal weighting" all indicators are given the same weight.

In order to determine the relative supply risks associated with the two technologies, we further aggregate the AHP-determined scores for the elements, namely, for $\mathrm{Cd}$ and $\mathrm{Te}$, on the one hand, and for $\mathrm{Cu}, \mathrm{In}, \mathrm{Ga}, \mathrm{Se}$ and $\mathrm{Mo}$, on the other. There are various possibilities for carrying out this aggregation process, of which we have used four in the present paper. Firstly, the simplest approach is to take the arithmetic mean, without any further weighting of the elements. Secondly, the "mass share" approach aggregates all elements according to their mass share in the solar cell. This aggregation would be in line with "mass allocation" approach in life cycle assessment studies [81]. Thirdly, the "cost share" approach considers only the economic risk of increased commodity prices due to supply risk by weighting each element according to its material cost share (calculated from mass share and commodity price [83]). This approach corresponds to the "economic allocation" in life cycle assessment studies [84]. It also reflects the school of thought in classical risk assessments which consider the likelihood of supply disruptions and economic consequences [85]. It assumes that price volatility is the main effect of supply disruptions - a consequence which is problematic only for those materials of high economic value. The fourth method is the "maximum" approach, which considers only the element with the highest supply risk score used in each technology. The abovementioned sensitivity analysis is also applied to these aggregated supply risks at the technology level. Finally, we perform a Monte-Carlo-based uncertainty analysis in order to calculate the effect of uncertainty distributions for all raw data on the supply risk scores at both the elemental and technology levels [86]. Differing raw data scales and varying data quality lead to differences in the uncertainty distribution, which are reported in the Supplementary Material. The result of this uncertainty analysis is a box-plot illustrating the possible overlap of resulting supply risk scores. 


\section{Results}

\subsection{Supply risk data}

We first assess and tabulate the raw supply risk data for the seven elements according to the eleven indicators. Looking at the value chain from extraction to tradeable products, we note that there are some fundamental differences between the seven elements which should not be underestimated. In the periodic table, cadmium, copper and molybdenum are transition metals, gallium and indium post-transition metals, tellurium is a metalloid and selenium a non-metal. Copper and molybdenum (although Mo is sometimes also extracted as a by-product in Cu mining) are mined in their own right. Their production tonnage is therefore generally reported as mining production $[69,87,88]$. The other elements are all by-products: $\mathrm{Cd}$ and In depend on zinc mining, Te and Se depend on copper, while $\mathrm{Ga}$ is a by-product of bauxite mining, which is the main ore of aluminum [24]. The production tonnages of by-products are generally reported in terms of refinery production $[69,89]$. Table 2 shows a summary of the data for all eleven supply risk indicators before normalization. A more detailed version with explanatory notes can be found in the Supplementary Material (Tables S11, S12, S13, S14, S15). Figures for the reserves and resources (needed for the static reaches) of mass metals like copper are readily available [90] and well discussed in the literature [91,92]. For minor metals, these estimates are sometimes more difficult to make and have therefore been calculated from by-product to host element ratios, and corresponding figures for reserves and resources of the host metal. These ratios may not be completely reliable, since they depend on the mineral extracted, the separation technology and the market situation, which taken together could lead to an overestimation of the long-term supply potential [93]. At this point it should be emphasized again that the term "static reach" is seen by the present authors more as measure of the market pressure for further mineral prospecting and subsequent mining activity than as a measure of possible supply risk due to mineral depletion [13].

\subsubsection{Risk of supply reduction}

Static reaches of reserves of the seven elements range from 23 years for In to more than 3000 years for $\mathrm{Ga}$. Static reaches of resources range from 73 years for Mo to more than 6000 years for Ga. For gallium, the annual production volume could significantly increase, if the existing supply potential from bauxite, sulphidic zinc ores and coal were to be exploited [94]. End-of-life recycling is estimated to be negligible for Te, In and Ga [95] (it is indeed negligible for many "rare" by-product metals), and unlikely to increase in the near future [96]. Although First Solar, for example, has operated a recycling service since 2005 [97], the amount of secondary material to become available is limited at present by the $25+$ year lifetime of the modules and by the fact that the large upsurge in installations only began in the last decade. The highest end-of-life recycling rate is found for $\mathrm{Cu}$, with 43\% [95].

\subsubsection{Risk of demand increase}

As mentioned above, many of the elements are only extracted as by-products in the mining of the host metal. For $\mathrm{Cd}, \mathrm{Te}, \mathrm{In}, \mathrm{Ga}$ and $\mathrm{Se}$, by-product dependence is taken as $100 \%$, with the host materials being $\mathrm{Zn}, \mathrm{Cu} / \mathrm{Pb}, \mathrm{Zn}$, bauxite and $\mathrm{Cu}$, respectively. Copper is sometimes (9\%) mined as a byproduct of nickel or gold. A significant amount of molybdenum is produced as a by-product of $\mathrm{Cu}$. It is expected that some of the seven elements will show a strong growth in demand due to them being essential functional components in future technologies: Angerer and colleagues [72] have estimated that from 2006 to 2030 Ga demand could grow by $581 \%$ (due to white LEDs, high-performance 
integrated circuits and thin-film photovoltaics), and that for In could grow by $289 \%$ (due to white LEDs, ITO for displays and thin-film photovoltaics). Cd, Te and Mo were not considered as essential for future technologies in that study. Nevertheless, these metals are also characterized by increasing production volumes; a lower boundary for future technology demand can be estimated in accordance with Kavlak et al. [47] based on historic production statistics. As the units for the expert opinion on "substitutability" are arbitrary, the results are displayed on a scale from 0 to 100. Generally, $\mathrm{Cd}$, Te, and $\mathrm{Ga}$ have quite rather well performing substitutes (e.g., $\mathrm{Li}, \mathrm{Bi}, \mathrm{Si}$ ), but for $\mathrm{Cu}$ and Mo it is hard to find replacements for their main applications (e.g. electrical circuits and power lines, steel, respectively).

\subsubsection{Concentration risk}

The "country" or "company" concentration, as expressed by the Herfindahl-Hirschman Index (HHI) has values between 0 and 10000, expressed as the sum over the squares of percentage market share. $\mathrm{Te}$, In and Ga show high country concentrations above 3000. The main reason is that not all countries use their refinery potential for these by-products [98]. Company concentration is generally lower than country concentration [99]. Nevertheless, the estimated company concentration scores for In and $\mathrm{Ga}$ are much higher (in a negative sense) than those for the other metals.

\subsubsection{Political risk}

The political risk scores do not vary much over the seven elements. Political stability, as expressed by the Worldwide Governance Indicator (WGI) score for political stability and absence of violence/terrorism, is given on a scale between -2.5 (very instable) and 2.5 (very stable) [78]. Selenium stands out in this regard, as it is predominantly used by the chemical industry and therefore its refining is concentrated in rather stable and industrialized countries. The Policy Perception Index (PPI) of the elements always refers to the host metal, with copper-mining countries being evaluated as being slightly more friendly to mining than is the case for countries where zinc, molybdenum and bauxite are extracted [79]. Since selenium is mainly produced in developed countries which are more likely to implement "not in my backyard" regulations, the corresponding regulation risk score is higher for selenium compared to other elements [80]. 
Table 2: Supply risk indicators on the elemental level before normalization. For explanations of the indicators and further information on assumptions concerning the data, see Supplementary Material. $\bigoplus$ : High figures mean high risk. $\ominus$ : Low figures mean high risk.

\begin{tabular}{|c|c|c|c|c|c|c|c|c|c|}
\hline Indicator & Dimension & Risk & $\mathrm{Cd}$ & $\mathrm{Te}$ & $\mathrm{Cu}$ & In & $\mathrm{Ga}$ & Se & Mo \\
\hline Static Reach Reserves & years & $\ominus$ & $28 a$ & $44 a$ & $37 a$ & $23 a$ & $3182 a$ & $53 a$ & $41 a$ \\
\hline Static Reach Resources & years & $\ominus$ & $267 a$ & $349 a$ & $299 a$ & $152 a$ & $6250 a$ & $422 a$ & $73 a$ \\
\hline End-of-Life Recycling Rate & $\%$ & $\ominus$ & $15 \%$ & $<1 \%$ & $43 \%$ & $<1 \%$ & $<1 \%$ & $<5 \%$ & $30 \%$ \\
\hline $\begin{array}{l}\text { By-product dependence } \\
\text { (Host metal/mineral) }\end{array}$ & $\%$ & $\oplus$ & $\begin{array}{l}100 \% \\
(Z n)\end{array}$ & $\begin{array}{l}100 \% \\
(\mathrm{Cu}, \\
\mathrm{Pb})\end{array}$ & $\begin{array}{l}9 \% \\
(\mathrm{Ni}, \mathrm{Au})\end{array}$ & $\begin{array}{l}100 \% \\
(Z n)\end{array}$ & $\begin{array}{l}100 \% \\
\text { (Bauxite) }\end{array}$ & $\begin{array}{l}100 \% \\
(\mathrm{Cu})\end{array}$ & $\begin{array}{l}46 \% \\
(\mathrm{Cu})\end{array}$ \\
\hline $\begin{array}{l}\text { Future Technology } \\
\text { Demand }\end{array}$ & $\%$ & $\bigoplus$ & $15 \%$ & $40 \%$ & $15 \%$ & $289 \%$ & $581 \%$ & $11 \%$ & $85 \%$ \\
\hline Substitutability & qualitative & $\ominus$ & 62 & 62 & 30 & 40 & 62 & 53 & 30 \\
\hline Country Concentration & $\mathrm{HHI}$ & $\oplus$ & 1670 & 3338 & 1443 & 3159 & 3785 & 2268 & 2323 \\
\hline Company Concentration & $\mathrm{HHI}$ & $\oplus$ & $\begin{array}{l}\text { rather } \\
\text { low }\end{array}$ & 1108 & 1108 & 1867 & 1667 & 1108 & 2183 \\
\hline WGI-PV & qualitative & $\ominus$ & -0.03 & 0.06 & 0.05 & 0.02 & -0.4 & 0.79 & $\begin{array}{l}- \\
0.02\end{array}$ \\
\hline PPI & qualitative & $\ominus$ & 43 & 55 & 55 & 43 & 47 & 55 & 47 \\
\hline HDI & qualitative & $\oplus$ & 0.79 & 0.73 & 0.76 & 0.80 & 0.71 & 0.88 & 0.79 \\
\hline
\end{tabular}

\subsection{Normalization \& weighting}

The result of putting the values from the different indicators onto a common scale of 0 to 100 is shown in Figure 3. The results from the normalization are listed in the Supplementary Material (Table S16). On this scale, high values always mean high supply risk. The range of values is narrow for "substitutability", "country concentration" and the "policy risk" indicators WGI, PPI and HDI. Simultaneously, the "static reach" for reserves and resources, the "by-product dependence" and the "future technology demand" show both very high and very low risk values. No element shows a very low risk for "end-of-life recycling rate", nor is a very high risk for "company concentration" apparent. The highest risk for a particular indicator is reached five times by gallium, four times by indium, three times by molybdenum, twice each by cadmium, tellurium and selenium, and once by copper. The lowest risk values are reached five times by copper, four times each by gallium, cadmium and tellurium, three times by selenium, and once by molybdenum. Indium is the exception in that it never has the lowest risk value. 




Figure 3: Supply risk values for all eleven indicators and all elements after normalization. [1.5-column fitting image]

As mentioned above, the relative weighting of the eleven supply risk indicators for the case of thinfilm photovoltaics was performed via an Analytic Hierarchy Process (AHP) involving ten international experts. The average of the weightings from all experts was then used as the overall weighting of the supply risk indicators, as given in Table 3 . The consistency ratios of all comparison matrices for the AHP were below the threshold and therefore the resulting weighting can be utilized. The highest single indicator weighting was found to be the "country concentration" $(21.9 \%)$, followed by "future technology demand" with $11.2 \%$ and company concentration with $9.4 \%$. Lowest weightings were assigned by the experts to "static reach of resources" (4.0\%) and "policy perception" with $5.5 \%$. 
Table 3: Indicator weighting according to the expert-based Analytic Hierarchy Process. For details on the AHP, see Supplementary Material.

\begin{tabular}{lll} 
Category & Indicator & Weighting \\
\hline Risk of Supply Reduction (20.0\%) & Static Reach Reserves & $6.6 \%$ \\
\cline { 2 - 3 } & Static Reach Resources & $4.0 \%$ \\
\cline { 2 - 3 } & End-of-Life Recycling Rate & $9.3 \%$ \\
\hline Risk of Demand Increase (23.4\%) & By-Product Dependence & $8.4 \%$ \\
\cline { 2 - 3 } & Future Technology Demand & $11.2 \%$ \\
\cline { 2 - 3 } & Substitutability & $9.7 \%$ \\
\hline Concentration Risk (31.3\%) & Country Concentration & $21.9 \%$ \\
\cline { 2 - 3 } & Company Concentration & $9.4 \%$ \\
\hline Policy Risk (19.4\%) & Political Stability & $7.8 \%$ \\
\cline { 2 - 3 } & Policy Perception & $5.5 \%$ \\
\cline { 2 - 3 } & Regulation & $6.1 \%$
\end{tabular}

\subsection{Supply risk on the elemental level}

Using the elemental supply risk indicators, the normalization routines and the indicator weightings determined via the Analytic Hierarchy Process, we obtain the overall risk values for substantial supply disruption of the seven elements considered, namely, cadmium, tellurium, copper, indium, gallium, selenium and molybdenum. These are given in Figure 4. (Figure S4 in the Supplementary Material shows a more detailed graph.) Indium shows the highest overall value (73), whereas copper shows the lowest (48). The high value for indium results from the low static reach, low end-of-life recycling rate, extraction as a by-product and the highest risk with respect to policy perception. Copper, on the other hand, is characterized by a high static reach of resources and the highest end-of-life recycling rate among these elements. Moreover, it is mostly extracted as a host metal, and shows a low country concentration as well as a low risk associated with policy perception. The other supply risk values are gallium (66), molybdenum (60), tellurium (59), selenium (58) and cadmium (52). A comparison with the other weighting scenarios in the sensitivity analysis (Supplementary Material, Table S24 and Figure S5) shows that for most of the elements a higher supply risk is obtained with the AHP-weighting than for equal weighting or group weighting. The largest difference is observed for Ga which is characterized by a supply risk of only 59 in the case of equal weighting (6 points less). The exception is Mo, which shows slightly higher supply risks for both alternative weightings. Thus, although the quantitative details differ, the order of the supply risk scores remains the same for the two alternative weightings. 


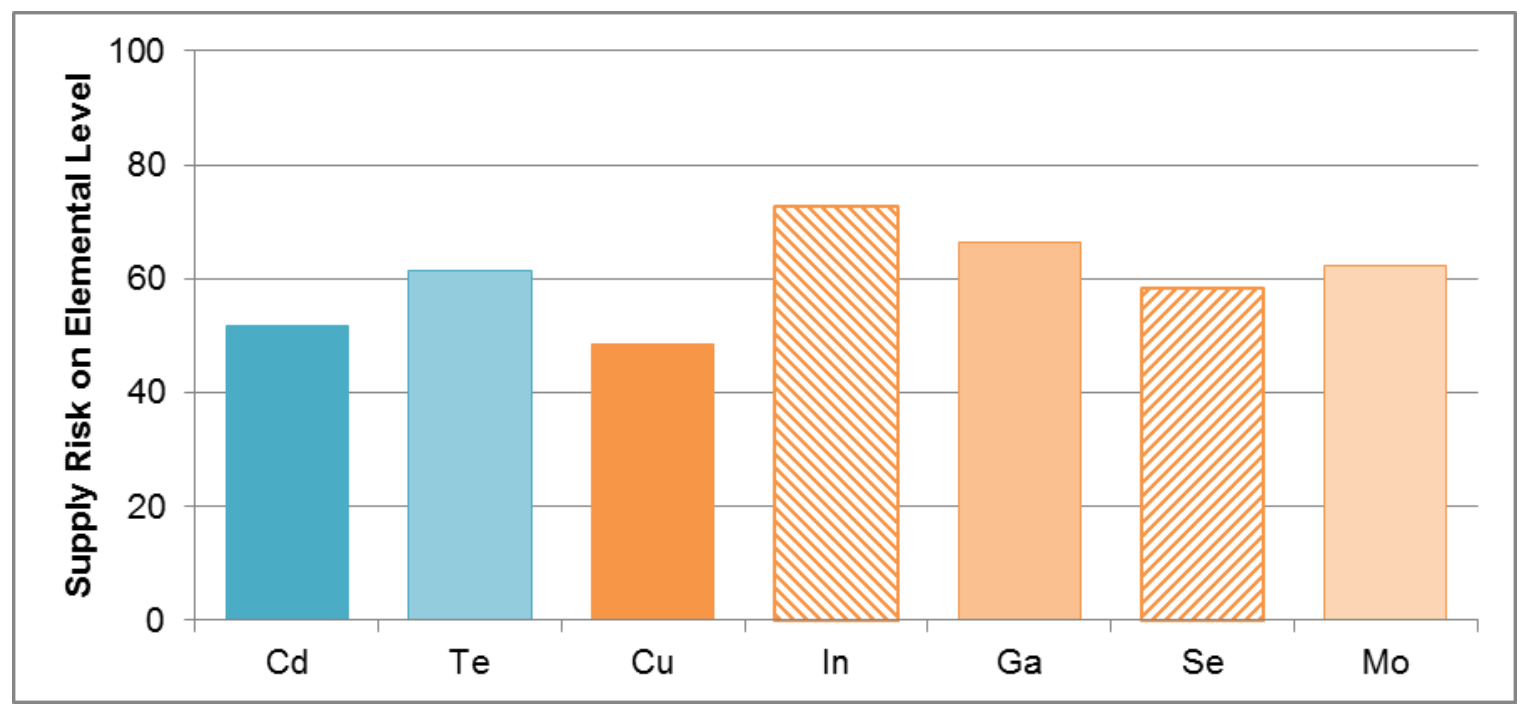

Figure 4: Elemental supply risks after aggregation of all indicators to a single value, following the AHPdetermined weightings. [single-column fitting image]

\subsection{Supply risk aggregation on the technology level}

Since the purpose of the present paper is a comparison of the two technologies rather than an analysis just involving the elements concerned, an aggregation of the results of Figure 4 is necessary. Of the many possible approaches only four have been chosen, as described in the methodology section. The results are shown in Figure 5. Using the arithmetic mean, CIGS (supply risk of 62) shows an about 5 points higher supply risk than CdTe (supply risk of 57). As $\mathrm{Cd}$ and Te have approximately the same weight in the CdTe layer, their relative contributions in the "mass share" approach hardly change, whereas the high mass share of Mo in the CIGS panel increases its importance for the CIGS supply risk value However, the overall "technology" supply risk remains approximately the same as for the arithmetic mean. The high commodity prices of Te and In increase the relative importance of these elements in the "cost share" approach. This increases the overall supply risk for both technologies as well as the difference between them (70 for CIGS against 61 for CdTe). In the fourth, "maximum" approach, which considers only the element with the highest supply risk score used in each technology, the supply risk values are determined by Te for CdTe and In for CIGS. In any case, the message comes across clearly that CdTe is characterized by somewhat lower supply risk values than CIGS for all aggregation options. This result is also obtained consistently for the alternative weighting scenarios, as shown by the sensitivity analysis (Supplementary Material, Figure S6). The equal weighting and group weighting again show lower supply risk scores in most cases (except for "CIGS mass share" where Mo has a high impact). 




Figure 5: Overall supply risks for the two technologies: results from different aggregation procedures. Arithmetic mean: each element has same weighting. "Mass-share" aggregation: elements are weighted according to their mass share in the photovoltaic layer. "Cost-share" aggregation: elements are weighted according to their raw material cost share. "Maximum" weighting: the element with highest supply risk determines the supply risk for the technology. [single-column fitting image]

\subsection{Uncertainty analysis}

Starting from the reported production data for individual countries, we have performed a Monte Carlo simulation for all of our collected data [86]. The results of this simulation lead to a box-plot chart for the supply risk results at the elemental and technology levels (see Figure 6). This chart shows a statistical summary (mean, median, quartiles, and outliers) of the supply risk results after 10000 random-number generated instances. The assumed distributions for all raw data within the simulation can be found in the Supplementary Material, table S25.

Half of the instances lead to supply risk values within a box between the $25^{\text {th }}$ and $75^{\text {th }}$ percentile. For the elemental level, the overlap of these boxes is low; standard deviations of the resulting elemental supply risk deviations are between 2 and 4 . Only Te und Mo show a strong overlap in the Monte Carlo simulation, making it impossible to state which of the two elements has the higher supply risk (which is not the intention here). On the technology level, the large gap between the two technologies is also persistent for all aggregation options. Thus, the main result of the article, namely the preference for CdTe over CIGS from a supply risk perspective is not compromised by data uncertainty. 
Elemental and Technology Supply Risk Monte Carlo Simulation

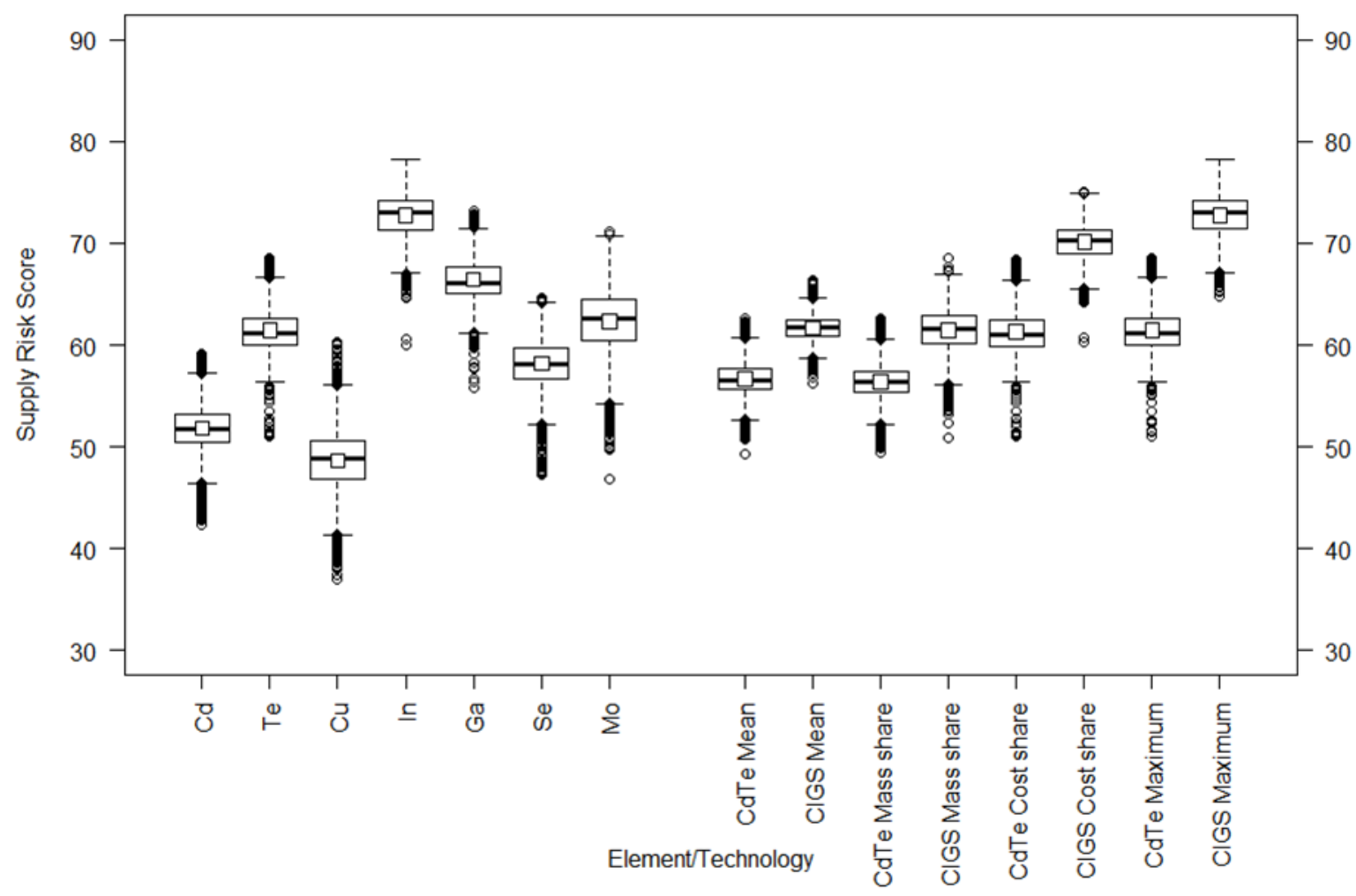

Figure 6: Comparison of supply risk scores on element level (left) and technology level (right). Box-plots display the median (thick line), mean (squares), the $25 \%$ and $75 \%$ percentiles (box), 1.5 interquartile ranges (whiskers), and outliers. Assumed distributions are listed in the Supplementary Material. [single-column fitting image]

\section{Discussion}

The results of the aggregation shown in Figure 5 can be used to identify which of the thin-film photovoltaic technologies is preferable from a supply risk point of view. The figures, resulting from the semi-quantitative supply risk assessment described above, are not a physical expression of scarcity, but rather a relative expression of mid- to long-term supply risks. We note that one of the major obstacles encountered during the present approach is data availability, which is particularly problematic for by-products and company data. Sometimes, data for single countries is withheld for reasons of confidentiality. The sources of the data for most indicators such as production and reserves as well as political indices, are normally revised annually, but some indicators such as future technology demand and recycling rate are only available from single publications that are not regularly updated. Filling the ensuing gaps with information from different sources can be problematic, since the precise definitions of terms such as "reserves" and "recycling-rates" may differ and assumptions made in secondary sources may be unclear. However, our overall results, in particular the preference obtained for CdTe over CIGS from a supply risk perspective, are robust against assumed data uncertainties, as illustrated by the Monte Carlo simulation.

The weighting of indicators by experts both directly in the field and in associated fields, rather than using equal or arbitrary weighting is a potential advantage, since it helps relevant risk criteria to be identified from different perspectives. However, our finding is that the number of experts prepared to co-operate in such an exercise is unfortunately low. We concede that at least double the number would have been ideal, with perhaps stronger participation by industry. Interestingly, the preference 
for CdTe is also the result obtained with group weighting and equal weighting, although the quantitative details differ. It will be interesting to see whether a similar observation will be made when our method is applied in future to the comparison of other technologies.

Several studies in the past have discussed the supply risk aspects associated with photovoltaic technologies, but usually on the basis of a single indicator, or only a few indicators. In a very early assessment, well before the current explosive growth in the installation of photovoltaic modules, Andersson [48] estimated that tellurium and indium availability (reserves/resources) would limit the deployment of CdTe and CIGS photovoltaics, as would germanium for amorphous silicon cells and ruthenium for dye-sensitized devices. The constraint was identified at $20 \mathrm{GWp}$ per year for CdTe and $70 \mathrm{GWp}$ per year for CIGS. [53]. In a review on different thin-film material, Candelise et al. [42] concluded in 2011 that the material prices (of indium and tellurium) are much more of a concern for the future of these technologies than the availability in terms of "reserves/resources". The main reason is that they would still have to compete with crystalline silicon as well as with emerging thinfilm technologies. (The latter have recently been described by Jean et al. [3].) According to the study of Kavlak et al. [47], the total deployment level of CdTe and CIGS modules could only reach $3 \%$ and $10 \%$, respectively, of global electricity generation by 2030 , if the historically observed $14.7 \%$ annual growth rate for all metals were to be reached. Jean et al. [3] estimated that for tellurium in CdTe it would require 1500 years at current production rates to reach a deployment level of 25 TWp (corresponding to $100 \%$ electricity production by the year 2050). Correspondingly shorter times would be required for gallium, indium and selenium for CIGS. In the case of cadmium, the current production rate would be sufficient to satisfy material demand, while the copper for CIGS would require only a fraction of current annual production. For the specific case of tellurium, it has been pointed out $[32,93]$ that reserve and resource figures are particularly difficult to estimate, because the metal, like selenium, is extracted mainly from the anode slime produced in electrolytic copper refining. However, the increased use of new electrowinning processes which do not allow tellurium to be captured, could impact future supply. Moreover, there are copper ores, mainly carbonates (malachites), which do not contain selenium or tellurium at all. The situation for selenium may be of less concern, since it could also be obtained as a by-product from nickel or coal. Viebahn et al. [53] have assessed the demand for rare metals required for an expansion of renewable energies in Germany up to 2050. In particular, they conclude that the supply of indium and selenium does not appear to be "secure" for CIGS in the long term. Reasons for this are geochemical availability, competing demand from other technologies, a high dependence on single suppliers and extraction as a by-product. Interestingly, they conclude that future research in thin-film photovoltaics should concentrate on cells containing little or no indium and selenium! Another interesting aspect has recently been discussed by Elshkaki and Graedel [46]. They point out that the increased demand for indium, for example, in photovoltaic applications could lead to an oversupply in the parent metal, zinc, as well as in another important by-product, cadmium. However, the latter could be partially mitigated by demand from the increasing deployment of CdTe modules.

Summing up these raw material evaluations for thin-film photovoltaics, we note that, with two exceptions, hitherto only reserve/resource availability has been investigated, i.e. technology-induced raw material demand is compared with reserves and resources. In the set of indicators used in the present work, these aspects are closely related to the two static reach indicators, end-of-life recycling rate and future technology demand. Interestingly, these four indicators combined account only for a weighting of $31.1 \%$ by the experts in the survey. Static reach of reserves and resources were only given a $10.4 \%$ weighting. Possibly, the low weighting given to these "classical" resource availability indicators is due to the fact that the experts were aware of the dynamic character of the 
reserve-to-production ratio and therefore did not want to overestimate the impact of this indicator. Indeed, several authors have in recent years warned against attaching too much significance to the figures for reserves and resources. A comparison of the reserves/resources data as reported by, for example, the USGS with the amounts of the elements contained in the Earth's continental crust reveals that the latter are generally many orders of magnitude higher. This seemingly paradoxical situation comes about because minerals are normally extracted from deposits where the average concentration of the element concerned (the mineral grade) is much higher than the crustal concentration. We still, however, speak of mineral depletion when mining companies are forced to exploit deposits of increasingly lower grade, or to mine under conditions of increasing difficulty, e.g. at greater depth, so that production costs increase. Due to more efficient techniques in the prospecting, mining and processing of ores these costs can in principle be absorbed, which is what has happened for most of the 20th century. Taken together, the terms "depletion" and "reserves/resources" imply, however, that exhaustion is close, which is not necessarily the case. This point makes clear why the definition, at least of reserves, and thus of the static reach of reserves, as used here, contains an economic component: In this paper we use the standard definition of reserves as being the quantity of the element concerned in those ores for which at the present time extraction is both technically and economically feasible (Section 3). The value gives an indication of the market pressure for further exploration and the development of new extraction technologies (Section 4.1). The corresponding value for resources is unfortunately less well defined because of the uncertainty in the data for the not yet identified resources, but may give some indication of possible future scarcity. This discussion demonstrates the importance in supply risk analyses of using a sufficient number of indicators (not just reserve/resource-linked ones) and to weight them specifically for the product or technological application under consideration.

In previous work, Goe and Gaustad [20] have identified critical materials for photovoltaics (siliconbased and thin-film) from the U.S. perspective using four supply-risk indicators, as well as an environmental and economic risk indicators. Due to their broader technology perspective, 17 elements are compared in total. Of the materials contained in CdTe and CIGS, In and Se have the highest "criticalities", Ga, Cu and Mo the lowest. Aggregation of the elemental values to compare CdTe and CIGS are not attempted in their study; however, the article includes policy recommendations for reducing the criticality of individual elements [20]. On the other hand, Graedel and Nuss [50], in their comparison of materials for thin-film photovoltaics using a multi-criteria catalogue, compare CdTe and CIGS as an example of the use of their "criticality" formalism and its applicability to product, or technology evaluation. They use previously determined "criticality values" ("criticality vector magnitude" - CVM) for each element based on an analysis using seven indicators covering three categories: supply risk aspects, vulnerability to supply risk and environmental impacts of raw material production. They employ an equal weighting for their indicators but also refrain from carrying out an aggregation at the product, or technology level. Instead, they discuss the CVM values for the individual elements and conclude that CdTe had a slight advantage over CIGS, in agreement with the present study. Decisive for their study was the high criticality value associated with indium, while still bearing in mind the lower one for cadmium [50].

\section{Summary}

When an increase in the market penetration of a promising future technology such as thin-film photovoltaics is expected, questions are raised concerning the mid- to long-term supply situation of the functional elements required. As new technologies typically involve more than one functional 
element, such as cadmium telluride (CdTe) and copper-indium-gallium diselenide ( $\mathrm{Culn}_{x} \mathrm{Ga}_{1-\mathrm{x}} \mathrm{Se}_{2}$ ), a multi-element assessment is required. Moreover, as many as possible relevant supply risks should be taken into account. Most assessments have hitherto focused only on some aspects of the problem, such as the availability of primary and secondary resources (in relation to current and future demand) or the by-product dependence. Moreover, the corresponding indicators are normally given an equal weighting which is not necessarily justified. When more than one element is involved, an appropriate aggregation procedure is also required for comparison of the technologies or devices.

In the present paper we use a set of eleven indicators, the choice of which is based on a broad literature survey. These indicators are then weighted with the help of an expert survey involving interviewees in research and industry. The results are especially evaluated for the comparison of the two photovoltaic technologies using an Analytic Hierarchy Process, which shows good consistency ratios. The highest weighting is given to the indicator "country concentration" (21.9\%), followed by "future technology demand" (11.2\%) and "company concentration" (9.4\%). The lowest weightings are given to "static reach of resources" (4.0\%) and the "policy perception" (5.5\%). We apply the eleven supply risk indicators to each functional element of CdTe and CIGS: cadmium, tellurium, copper, indium, gallium, selenium and molybdenum. Among these, copper and cadmium show the lowest supply risk, indium and gallium the highest. The rather low risk for copper emerges from a low country and company concentration combined with a moderate future technology demand and the fact that copper is mainly a host metal. The same indicators are responsible for the higher supply risks for indium and gallium.

In a second step, four different aggregation methods are compared in order to evaluate whole technologies: "average supply risks" of the single elements, the "mass-weighted supply risk", the "cost-weighted supply risk" and the "maximum supply risk". CdTe shows a slightly lower supply risk for all aggregation options than CIGS. The mass-weighted supply risk for CIGS is mainly determined by molybdenum. While the cost-based supply risk for $\mathrm{CdTe}$ is determined largely by cadmium, the cost-based supply risk of CIGS is strongly influenced by indium. These different aggregation options at the technology level could reflect different priorities set by decision-makers and can be chosen in such a way as to be compatible with a particular supply risk assessment.

In conclusion, we have presented in this paper a semi-quantitative, relative supply risk assessment of the two thin-film photovoltaic technologies, CdTe and CIGS. It transpires that marginally less supply risk is associated with the use of CdTe technology than with CIGS. The significance of the present analysis lies not just in this result, but also in the successful application of the procedure on a comparative basis at the technology level. It has been demonstrated that suitable indicators can be identified, the required data are generally available and the normalization and weighting procedures are feasible. Moreover, the preference for CdTe is maintained for other, simpler weightings (although the quantitative details vary) and the results are robust with respect to data uncertainties. Our procedure can now be applied to other technologies where such a comparative supply risk assessment is required. In principle, the procedure could be extended to include environmental and social aspects. Whilst these aspects are of course very important, there is, however, no a priori reason why they should be included in an analysis of supply risk.

\section{Acknowledgements}

This work was supported by the Bavarian State Ministry of Education, Science and the Arts in form the of the graduate program "Resource strategy concepts for sustainable energy systems" at the Institute of Materials Resource Management (MRM) of the University of Augsburg, Germany. We 
particularly thank all participants of the AHP questionnaire. One of us (AMB) acknowledges useful discussions with B. Reuter. We would like to thank two anonymous reviewers for extensive feedback on the manuscript.

\section{Appendix A. Supplementary material}

Supplementary data associated with this article can be found, in the online version.

\section{References}

[1] Mints P. The history and future of incentives and the photovoltaic industry and how demand is driven. Prog Photovoltaics Res Appl 2012;20:711-6. doi:10.1002/pip.1214.

[2] Bettencourt LMA, Trancik JE, Kaur J. Determinants of the Pace of Global Innovation in Energy Technologies. PLoS One 2013;8:e67864. doi:10.1371/journal.pone.0067864.

[3] Jean J, Brown PR, Jaffe RL, Buonassisi T, Bulovic V, Bulović V. Pathways for solar photovoltaics. Energy Environ Sci 2015;8:1200-19. doi:10.1039/C4EE04073B.

[4] IEA. Snapshot of Global PV Markets. 2014.

[5] IEA. Key World Energy Statistics 2014.

[6] U.S. National Research Council. Minerals, Critical Minerals, and the U.S. Economy. Washington, DC: The National Academies Press; 2008.

[7] European Commission. Critical Raw Materials for the EU. 2010.

[8] Erdmann L, Graedel TE. Criticality of Non-Fuel Minerals: A Review of Major Approaches and Analyses. Environ Sci Technol 2011;45:7620-30. doi:10.1021/es200563g.

[9] Graedel TE, Harper EM, Nassar NT, Nuss P, Reck BK. Criticality of metals and metalloids. Proc Natl Acad Sci 2015;112:4257-62. doi:10.1073/pnas.1500415112.

[10] Meadows DH, Meadows DL, Randers J, Behrens WW. Limits to Growth. Washington D.C.: Potomac Associates; 1972.

[11] Goeller HE, Weinberg AM. The Age of Substitutability. Science (80- ) 1976;191:683-9.

[12] Simon J. Resources, population, environment: an oversupply of false bad news. Science (80- ) 1980;208:1431-7. doi:10.1126/science.7384784.

[13] Tilton JE. On Borrowed Time: Assessing the Threat of Mineral Depletion. Resources for the Future; 2002.

[14] Allwood JM, Ashby MF, Gutowski TG, Worrell E. Material efficiency: A white paper. Resour Conserv Recycl 2011;55:362-81. doi:10.1016/j.resconrec.2010.11.002.

[15] Craig JR, Vaughan DJ, Skinner BJ. Resources of the earth: origin, use, and environmental impact. 4th ed. Prentice Hall; 2011.

[16] Rosenau-Tornow D, Buchholz P, Riemann A, Wagner M. Assessing the long-term supply risks for mineral raw materials-a combined evaluation of past and future trends. Resour Policy 2009;34:161-75. doi:10.1016/j.resourpol.2009.07.001.

[17] Erdmann L, Behrendt S, Feil M. Kritische Rohstoffe für Deutschland. Berlin: KfW Bankengruppe; 2011.

[18] Graedel TE, Barr R, Chandler C, Chase T, Choi J, Christoffersen L, et al. Methodology of Metal Criticality Determination. Environ Sci Technol 2012;46:1063-70. doi:10.1021/es203534z.

[19] Achzet B, Helbig C. How to evaluate raw material supply risks-an overview. Resour Policy 2013;38:435-47. doi:10.1016/j.resourpol.2013.06.003. 
[20] Goe M, Gaustad G. Identifying critical materials for photovoltaics in the US: A multi-metric approach. Appl Energy 2014;123:387-96. doi:10.1016/j.apenergy.2014.01.025.

[21] Roelich K, Dawson DA, Purnell P, Knoeri C, Revell R, Busch J, et al. Assessing the dynamic material criticality of infrastructure transitions: A case of low carbon electricity. Appl Energy 2014;123:378-86. doi:http://dx.doi.org/10.1016/j.apenergy.2014.01.052.

[22] Hatayama H, Tahara K. Criticality Assessment of Metals for Japan's Resource Strategy. Mater Trans 2015;56:229-35. doi:10.2320/matertrans.M2014380.

[23] Pfleger P, Lichtblau K, Bardt H, Bertenrath R. Rohstoffsituation der bayerischen Wirtschaft. München: 2015.

[24] Nassar NT, Graedel TE, Harper EM. By-product metals are technologically essential but have problematic supply. Sci Adv 2015;1:e1400180. doi:10.1126/sciadv.1400180.

[25] Haas W, Krausmann F, Wiedenhofer D, Heinz M. How Circular is the Global Economy?: An Assessment of Material Flows, Waste Production, and Recycling in the European Union and the World in 2005. J Ind Ecol 2015;19:765-77. doi:10.1111/jiec.12244.

[26] Zimmermann T, Gößling-Reisemann S. Recycling Potentials of Critical Metals-Analyzing Secondary Flows from Selected Applications. Resources 2014;3:291-318. doi:10.3390/ resources3010291.

[27] European Commission. Report on Critical Raw Materials for the EU: Report of the Ad hoc Working Group on defining critical raw materials. Brussels, Belgium: European Commission; 2014.

[28] American Physical Society, Materials Research Society. Energy Critical Elements. 2011.

[29] Krohns S, Lunkenheimer P, Meissner S, Reller A, Gleich B, Rathgeber A, et al. The route to resource-efficient novel materials. Nat Mater 2011;10:899-901. doi:10.1038/nmat3180.

[30] Moss RL, Tzimas E, Kara H, Willis P, Kooroshy J. Critical Metals in Strategic Energy Technologies. Luxembourg: European Commission; 2011.

[31] Lehner F, Rastogi A, Sengupta S, Vuille F, Ziem S. Securing the supply chain for wind and solar energy (RE-SUPPLY). 2012.

[32] Bradshaw AM, Reuter B, Hamacher T. The Potential Scarcity of Rare Elements for the Energiewende. Green 2013;3:93-111. doi:10.1515/green-2013-0014.

[33] Moss RL, Tzimas E, Willis P, Arendorf J, Tercero Espinoza L. Critical Metals in the Path towards the Decarbonisation of the EU Energy Sector. European Commission, Joint Research Centre, Intitute for Energy and Transport; 2013.

[34] Schriefl E, Bruckner M, Haider A, Windhaber M. Metallbedarf von Erneuerbare-EnergieTechnologien. Wien: energieautark consulting GmbH, SERI; 2013.

[35] Vidal O, Goffé B, Arndt N. Metals for a low-carbon society. Nat Geosci 2013;6:894-6. doi:10.1038/ngeo1993.

[36] Vikström H, Davidsson S, Höök M. Lithium availability and future production outlooks. Appl Energy 2013;110:252-66. doi:10.1016/j.apenergy.2013.04.005.

[37] Arent D, Pless J, Mai T, Wiser R, Hand M, Baldwin S, et al. Implications of high renewable electricity penetration in the U.S. for water use, greenhouse gas emissions, land-use, and materials supply. Appl Energy 2014;123:368-77. doi:10.1016/j.apenergy.2013.12.022.

[38] Izatt RM, Izatt SR, Bruening RL, Izatt NE, Moyer BA. Challenges to achievement of metal sustainability in our high-tech society. Chem Soc Rev 2014;43:2451. doi:10.1039/c3cs60440c. 
[39] Kim J, Guillaume B, Chung J, Hwang Y. Critical and precious materials consumption and requirement in wind energy system in the EU 27. Appl Energy 2015;139:327-34. doi:10.1016/j.apenergy.2014.11.003.

[40] Zepf V, Simmons J, Reller A, Ashfield M, Rennie C. Materials critical to the energy industry. An Introduction. 2nd ed. London: BP p.I.c.; 2014.

[41] Bergesen JD, Heath GA, Gibon T, Suh S. Thin-Film Photovoltaic Power Generation Offers Decreasing Greenhouse Gas Emissions and Increasing Environmental Co-benefits in the Long Term. Environ Sci Technol 2014;48:9834-43. doi:10.1021/es405539z.

[42] Candelise C, Speirs JF, Gross RJK. Materials availability for thin film (TF) PV technologies development: A real concern? Renew Sustain Energy Rev 2011;15:4972-81. doi:10.1016/j.rser. 2011.06.012.

[43] Zuser A, Rechberger $\mathrm{H}$. Considerations of resource availability in technology development strategies: The case study of photovoltaics. Resour Conserv Recycl 2011;56:56-65. doi:10.1016/ j.resconrec.2011.09.004.

[44] Marwede M, Reller A. Estimation of life cycle material costs of cadmium telluride- and copper indium gallium diselenide-photovoltaic absorber materials based on life cycle material flows. $J$ Ind Ecol 2014;18:254-67. doi:10.1111/jiec.12108.

[45] Stamp A, Wäger PA, Hellweg S. Linking energy scenarios with metal demand modeling-The case of indium in CIGS solar cells. Resources 2014;93:156-67. doi:10.1016/j.resconrec.2014.10.012.

[46] Elshkaki A, Graedel TE. Solar cell metals and their hosts: A tale of oversupply and undersupply. Appl Energy 2015;158:167-77. doi:10.1016/j.apenergy.2015.08.066.

[47] Kavlak G, McNerney J, Jaffe RL, Trancik JE. Metal production requirements for rapid photovoltaics deployment. Energy Environ Sci 2015;8:1651-9. doi:10.1039/C5EE00585J.

[48] Andersson BA. Materials availability for large-scale thin-film photovoltaics. Prog Photovoltaics Res Appl 2000;8:61-76. doi:10.1002/(SICI)1099-159X(200001/02)8:1<61::AID-PIP301>3.0.CO;26.

[49] Anctil A, Fthenakis V. Critical metals in strategic photovoltaic technologies: abundance versus recyclability. Prog Photovoltaics Res Appl 2013:1253-9. doi:10.1002/pip.2308.

[50] Graedel TE, Nuss P. Employing Considerations of Criticality in Product Design. JOM 2014;66:2360-6. doi:10.1007/s11837-014-1188-4.

[51] Jarrett R, Dawson D, Roelich K, Purnell P. Calculating material criticality of transparent conductive electrodes used for thin film and third generation solar cells. 2014 IEEE 40th Photovolt. Spec. Conf., IEEE; 2014, p. 1436-41. doi:10.1109/PVSC.2014.6925186.

[52] Grandell L, Höök M. Assessing Rare Metal Availability Challenges for Solar Energy Technologies. Sustainability 2015;7:11818-37. doi:10.3390/su70911818.

[53] Viebahn P, Soukup O, Samadi S, Teubler J, Wiesen K, Ritthoff M. Assessing the need for critical minerals to shift the German energy system towards a high proportion of renewables. Renew Sustain Energy Rev 2015;49:655-71. doi:10.1016/j.rser.2015.04.070.

[54] Harper EM, Kavlak G, Burmeister L, Eckelman MJ, Erbis S, Sebastian Espinoza V, et al. Criticality of the Geological Zinc, Tin, and Lead Family. J Ind Ecol 2015;19:628-44. doi:10.1111/jiec.12213.

[55] Nassar NT, Barr R, Browning M, Diao Z, Friedlander E, Harper EM, et al. Criticality of the geological copper family. Environ Sci Technol 2012;46:1071-8. doi:10.1021/es203535w.

[56] Tuma A, Reller A, Thorenz A, Kolotzek C, Helbig C. Nachhaltige Ressourcenstrategien in Unternehmen: Identifikation kritischer Rohstoffe und Erarbeitung von Handlungsempfehlungen 
zur Umsetzung einer ressourceneffizienten Produktion. Augsburg: Universtität Augsburg, Deutsche Bundesstiftung Umwelt; 2014.

[57] NREL. Polycrystalline Thin Films 2015. http://www.nrel.gov/pv/thinfilm.html (accessed May 6, 2016).

[58] McEvoy A, Castaner L, Markvart T. Solar Cells. 2nd ed. Waltham: Academic Press; 2012.

[59] Burger B, Kiefer K, Kost C, Nold S, Philipps S, Preu R, et al. Photovoltaics Report. 2015. doi:26.05.2014.

[60] Green MA, Emery K, Hishikawa Y, Warta W, Dunlop ED. Solar cell efficiency tables (version 46). Prog Photovoltaics Res Appl 2015;23:805-12. doi:10.1002/pip.2637.

[61] Jeon NJ, Noh JH, Yang WS, Kim YC, Ryu S, Seo J, et al. Compositional engineering of perovskite materials for high-performance solar cells. Nature 2015;517:476-80. doi:10.1038/nature14133.

[62] Bhandari KP, Collier JM, Ellingson RJ, Apul DS. Energy payback time (EPBT) and energy return on energy invested (EROI) of solar photovoltaic systems: A systematic review and meta-analysis. Renew Sustain Energy Rev 2015;47:133-41. doi:10.1016/j.rser.2015.02.057.

[63] First Solar. First Solar achieves world record 18.6 \% thin film module conversion efficiency 2015. http://investor.firstsolar.com/releasedetail.cfm?ReleaselD=917926 (accessed September 22, 2015).

[64] Yoon J-H, Yoon K-H, Kim WM, Park J-K, Baik Y-J, Seong T-Y, et al. High-temperature stability of molybdenum (Mo) back contacts for CIGS solar cells: a route towards more robust back contacts. J Phys D Appl Phys 2011;44:425302. doi:10.1088/0022-3727/44/42/425302.

[65] Ma X, Liu D, Yang L, Zuo S, Zhou M. Eighth International Conference on Thin Film Physics and Applications. Eighth Int. Conf. Thin Film Phys. Appl., vol. 9068, 2013, p. 906814.

[66] Bätzner D., Romeo A, Zogg H, Wendt R, Tiwari A. Development of efficient and stable back contacts on CdTe/CdS solar cells. Thin Solid Films 2001;387:151-4. doi:10.1016/S00406090(01)00792-1.

[67] Paudel NR, Yan Y. CdTe thin-film solar cells with cobalt-phthalocyanine back contacts. Appl Phys Lett 2014;104:143507. doi:10.1063/1.4871093.

[68] Graedel TE, Reck BK. Six Years of Criticality Assessments: What Have We Learned So Far? J Ind Ecol 2015;00:n/a - n/a. doi:10.1111/jiec.12305.

[69] USGS. Mineral Commodity Summaries 2015. U.S. Geological Survey; 2015.

[70] Graedel TE, Allwood J, Birat J-P, Buchert M, Hagelüken C, Reck BK, et al. What Do We Know About Metal Recycling Rates? J Ind Ecol 2011;15:355-66. doi:10.1111/j.15309290.2011.00342.x.

[71] Afflerbach P, Fridgen G, Keller R, Rathgeber AW, Strobel F. The by-product effect on metal markets - New insights to the price behavior of minor metals. Resour Policy 2014;42:35-44. doi:10.1016/j.resourpol.2014.08.003.

[72] Angerer G, Marscheider-Weidemann F, Lüllmann A, Erdmann L, Scharp M, Handke V, et al. Raw Materials for Emerging Technologies. Stuttgart: Frauenhofer IRB Verlag; 2009.

[73] Habib K, Wenzel H. Reviewing resource criticality assessment from a dynamic and technology specific perspective - using the case of direct-drive wind turbines. J Clean Prod 2016;112:385263. doi:10.1016/j.jclepro.2015.07.064.

[74] Graedel TE, Harper EM, Nassar NT, Reck BK. On the materials basis of modern society. Proc Natl Acad Sci 2015;112:6295-300. doi:10.1073/pnas.1312752110. 
[75] Helbig C, Wietschel L, Thorenz A, Tuma A. How to evaluate raw material vulnerability - An overview. Resour Policy 2016;48:13-24. doi:10.1016/j.resourpol.2016.02.003.

[76] Calkins S. The New Merger Guidelines and the Herfindahl-Hirschman Index. Calif Law Rev 1983;71:402. doi:10.2307/3480160.

[77] Kaufmann D, Kraay A, Mastruzzi M. The Worldwide Governance Indicators: Methodology and Analytical Issues. World Bank Policy Res Work Pap 2010;5430.

[78] Kaufmann D, Kraay A. Worldwide Governance Indicators 2015. http://info.worldbank.org/ governance/wgi/index.aspx\#home (accessed December 1, 2015).

[79] Jackson T, Green KP. Fraser Institute Annual Survey of Mining Companies, 2014. 2015.

[80] UNDP. Human Development Report 2014. 2014.

[81] Schneider L, Berger M, Schüler-Hainsch E, Knöfel S, Ruhland K, Mosig J, et al. The economic resource scarcity potential (ESP) for evaluating resource use based on life cycle assessment. Int J Life Cycle Assess 2014;19:601-10. doi:10.1007/s11367-013-0666-1.

[82] Saaty TL. Decision making with the analytic hierarchy process. Int J Serv Sci 2008;1:83. doi:10.1504/IJSSCI.2008.017590.

[83] DERA. DERA Preismonitor August 2015. 2015.

[84] Nuss P, Eckelman MJ. Life Cycle Assessment of Metals: A Scientific Synthesis. PLoS One 2014;9:e101298. doi:10.1371/journal.pone.0101298.

[85] Glöser S, Tercero Espinoza L, Gandenberger C, Faulstich M. Raw material criticality in the context of classical risk assessment. Resour Policy 2015;44:35-46. doi:10.1016/j.resourpol. 2014.12.003.

[86] Root DH, Menzie WD, Scott WA. Computer Monte Carlo simulation in quantitative resource estimation. Nonrenewable Resour 1992;1:125-38. doi:10.1007/BF01782266.

[87] Geoscience Australia. Australia's Identified Mineral Resources 2013. Canberra: 2013.

[88] Natural Resources Canada. Preliminary estimate of the mineral production of Canada, by province, 2014 2015. http://sead.nrcan.gc.ca/prod-prod/2014p-eng.aspx (accessed March 25, 2015).

[89] USGS. Minerals Yearbook 2012: Volume I - Metals and Minerals. 2013.

[90] SNL Metals \& Mining. Raw Materials Data. Version 20. Sweden: 2014.

[91] Johnson KM, Hammarstrom JM, Zientek ML, Dicken CL. Estimate of Undiscovered Copper Resources of the World, 2013. 2014.

[92] Schwarz-Schampera U. Indium. In: Gunn G, editor. Crit. Met. Handb., John Wiley \& Sons; 2014, p. 204-29.

[93] Bustamante ML, Gaustad G. Challenges in assessment of clean energy supply-chains based on byproduct minerals: A case study of tellurium use in thin film photovoltaics. Appl Energy 2014;123:397-414. doi:10.1016/j.apenergy.2014.01.065.

[94] Frenzel M, Ketris MP, Seifert T, Gutzmer J. On the current and future availability of gallium. Resour Policy 2016;47:38-50. doi:10.1016/j.resourpol.2015.11.005.

[95] Graedel TE, Allwood J, Birat J-P, Reck BK, Sibley SF, Sonnemann G, et al. Recycling Rates of Metals - A Status Report, A Report of the Working Group on the Global Metal Flows to the International Resource Panel. UNEP; 2011.

[96] Løvik AN, Restrepo E, Müller DB. The Global Anthropogenic Gallium System: Determinants of Demand, Supply and Efficiency Improvements. Environ Sci Technol 2015;49:5704-12. doi:10.1021/acs.est.5b00320. 
[97] First Solar. The Recycling Advantage n.d. http://firstsolar.com/Technologies-and-Capabilities/ Recycling-Services (accessed April 28, 2015).

[98] Licht C, Peiró LT, Villalba G. Global Substance Flow Analysis of Gallium, Germanium, and Indium: Quantification of Extraction, Uses, and Dissipative Losses within their Anthropogenic Cycles. J Ind Ecol 2015;19:890-903. doi:10.1111/jiec.12287.

[99] Buchholz P, Huy D, Sievers H. DERA-Rohstoffliste 2012. 2012. 
Postprint

\title{
Supply Risks Associated with CdTe and CIGS Thin-Film Photovoltaics
}

\section{Appendix A: Supplementary data}

\author{
Christoph Helbiga ${ }^{a}$ Alex M. Bradshaw ${ }^{b, c}$, Christoph Kolotzek ${ }^{a}$, Andrea Thorenz ${ }^{a}$, Axel Tuma \\ *Address correspondence to: christoph.helbig@wiwi.uni-augsburg.de \\ ${ }^{a}$ : Resource Lab, Institute of Materials Resource Management, University of Augsburg, \\ Universitaetsstr. 16, 86159 Augsburg, Germany \\ b: Max Planck Institute for Plasma Physics, Boltzmannstraße 2, 85748 Garching, Germany \\ ': Fritz Haber Institute, Faradayweg 4-6, 14195 Berlin, Germany
}

Supplementary Material to:

Helbig C., et al., Supply Risks Associated with CdTe and CIGS Thin-Film Photovoltaics, Applied Energy 178 (2016), available at https://doi.org/10.1016/j.apenergy.2016.06.102

\begin{tabular}{|c|c|c|c|}
\hline Section Topic & Tables & Figures & Page \\
\hline 1. Short explanation of the eleven indicators & S1, S2 & & S2 \\
\hline 2. Country-specific elemental data tables & S3 - S10 & & S4 \\
\hline 3. Supply risk data table with notes and comments & $\mathrm{S} 11-\mathrm{S} 16$ & & S10 \\
\hline 4. Expert questionnaire fore supply risk indicator weighting & S17-S21 & $\mathrm{S} 1-\mathrm{S} 3$ & S13 \\
\hline 5. Supply risk aggregation information for $\mathrm{CdTe}$ and $\mathrm{CIGS}$ & S22, S23 & S4 & S17 \\
\hline 6. Sensitivity analysis: Alternative weighting scenarios & S24 & S5, S6 & S19 \\
\hline 7. Monte Carlo simulation for uncertainty analysis & S25 & & S21 \\
\hline References & & & S22 \\
\hline
\end{tabular}




\section{Short explanation of the eleven indicators}

Table S4: Explanation of supply risk indicators in the categories "risk of supply reduction" and "risk of demand increase".

\begin{tabular}{|c|c|c|c|c|c|c|c|}
\hline & Indicator & Indicator Description & Unit & Min & $\operatorname{Max}$ & Calculation & Sources \\
\hline \multirow{3}{*}{ 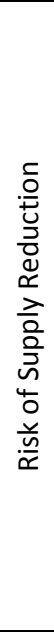 } & $\begin{array}{l}\text { Static Reach } \\
\text { Reserves }\end{array}$ & $\begin{array}{l}\text { The static reach of the reserves (SR) of a raw material is measured by the ratio of annual } \\
\text { primary production to the estimated global reserves. Reserves are the ores currently } \\
\text { technically and economically extractable from known deposits. The value gives an } \\
\text { indication of the market pressure for further exploration and for the development of new } \\
\text { extraction capabilities, possibly leading to higher price levels. }\end{array}$ & years & 0 years & $\begin{array}{l}\text { infinite } \\
\text { ( } \infty \text { years) }\end{array}$ & $S_{1}=100-0.2 \mathrm{SR}-0.008 \mathrm{SR}^{2}[1]$ & [2] \\
\hline & $\begin{array}{l}\text { Static Reach } \\
\text { Resources }\end{array}$ & $\begin{array}{l}\text { The static reach of the resources (RR) of a raw material is measured by the ratio of annual } \\
\text { production to estimated global resources. Resources are deposits from which the economic } \\
\text { extraction of the ore is potentially feasible, but not at present. The value is the best } \\
\text { available measure of a possible physical scarcity of a raw material due to potential mineral } \\
\text { depletion, independent of current price levels. }\end{array}$ & years & 0 years & $\begin{array}{l}\text { infinite } \\
(\infty \text { years) }\end{array}$ & $S_{2}=100-0.1 \mathrm{RR}-0.002 \mathrm{RR}^{2}[1]$ & [2] \\
\hline & $\begin{array}{l}\text { EoL-Recycling } \\
\text { Rate }\end{array}$ & $\begin{array}{l}\text { The end-of-life recycling rate (EOL-RR) of a raw material is measured by the ratio of current } \\
\text { annual recycled material flow to the annual discard rate of the raw material. The value } \\
\text { gives an estimate of the amount of available secondary material, which is independent of } \\
\text { mining and primary refining activities and can thus smooth out supply disruptions or price } \\
\text { peaks. }\end{array}$ & $\%$ & $0 \%$ & $100 \%$ & $S_{3}=100-$ EoL-RR & [3] \\
\hline \multirow{3}{*}{ 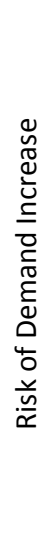 } & $\begin{array}{l}\text { By-Product } \\
\text { Dependence }\end{array}$ & $\begin{array}{l}\text { The by-product dependence (BPD) is the percentage of the element mined as a byproduct } \\
\text { of the global production of another element. This is normally the case, when mining solely } \\
\text { for the raw material itself is not economically feasible. This figure is a measure of the } \\
\text { potential inability to increase primary production in response to an increase in demand. }\end{array}$ & $\%$ & $0 \%$ & $100 \%$ & $S_{4}=\mathrm{BPD}$ & {$[4]$} \\
\hline & $\begin{array}{l}\text { Future } \\
\text { Technology } \\
\text { Demand }\end{array}$ & $\begin{array}{l}\text { Future technology demand (FTD) is given by the ratio of expected additional demand in a } \\
\text { future year due to new, future technologies and global production in a past year. The value } \\
\text { gives an indication of the market pressure for increasing global extraction due to future } \\
\text { technologies and therefore of potential additional competition in the commodity markets. }\end{array}$ & $\%$ & $0 \%$ & $\begin{array}{l}\text { infinite } \\
(\infty \%)\end{array}$ & $\begin{array}{l}S_{5}=((\sqrt[t]{(1+\mathrm{FTD})})-1) * 1000 \\
\mathrm{t}=24 \text { years }[5]\end{array}$ & {$[6]$} \\
\hline & Substitutability & $\begin{array}{l}\text { Substitutability (Subst) is an estimate of the extent to which a raw material can be replaced } \\
\text { by another raw material, without there being a too great a loss of essential properties. It is } \\
\text { gauged by expert assessment. The value gives an estimates of the extent to which demand } \\
\text { can be shifted to other materials in case of supply shortage and thus of the potential to } \\
\text { smooth out supply disruptions or price peaks. }\end{array}$ & $\begin{array}{l}\text { dimension- } \\
\text { less }\end{array}$ & 0 & 100 & $S_{6}=100-$ Subst & [7] \\
\hline
\end{tabular}


Table S5: Explanation of supply risk indicators in the categories "concentration risk" and "political risk".
Indicator Indicator Description

Unit

Min Max

Calculation

Sources

Country

The concentration of the annual production of a raw material at the country level

Concentration

is measured by the Herfindahl-Hirschman Index, which is the sum over the squares of the production shares of the countries in percent. The value indicates


directly market concentration in a few countries and thus the possibility of strategic exploitation of a monopolistic position at times of international crisis or dispute.

Company The concentration of the annual production of a raw material at the company $\stackrel{\bigcup}{0}$ Concentration

level is measured by the Herfindahl-Hirschman Index, which is the sum over the squares of the production shares of the companies in percent. The value indicates directly market concentration in a few companies and thus the likelihood of oligopolistic structures, which are linked in turn to higher price levels, low levels of competition and strategic misuse.

\begin{tabular}{|c|c|c|}
\hline \multirow{3}{*}{ 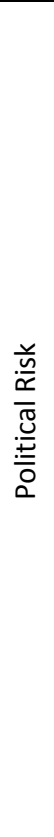 } & $\begin{array}{l}\text { Country Risk } \\
\text { Political Stability }\end{array}$ & $\begin{array}{l}\text { The risk of political instability in producing countries is measured by the } \\
\text { Worldwide Governance Indicator for Political Stability and Absence of } \\
\text { Violence/Terrorism, presented by the World Bank, weighted by the production } \\
\text { share in each producing country. The value is an indication of the likelihood of } \\
\text { disruption in production and export in the countries concerned due to unrest, } \\
\text { coups d'état, terrorism or other situations involving violence. }\end{array}$ \\
\hline & $\begin{array}{l}\text { Country Risk } \\
\text { Policy Perception }\end{array}$ & $\begin{array}{l}\text { The indicator Policy Perception is an assessment of the ability of producing } \\
\text { countries to implement new mining projects, weighted by the production share in } \\
\text { each country. The Policy Perception is evaluated by mining industry experts and } \\
\text { summarized by the Fraser Institute. The value is a measure of the ability of the } \\
\text { market to continue to function and/or of primary production to increase further } \\
\text { based on the rule of law and governance procedures in producing countries. }\end{array}$ \\
\hline & $\begin{array}{l}\text { Country Risk } \\
\text { Regulation }\end{array}$ & $\begin{array}{l}\text { The "regulation risk" attempts to measure the likelihood of the producing } \\
\text { countries to actually implement restrictions on mining, refining and trade, as } \\
\text { indicated by their level of societal development. This in turn is measured by the } \\
\text { HDI (Human Development Index), as presented by the United Nations } \\
\text { Development Programme and weighted by the production share in each } \\
\text { producing country. The value assesses the likelihood that further mineral } \\
\text { extraction and refining activities are prevented due to regulations, taxes, tariffs or } \\
\text { taxes in producing countries. }\end{array}$ \\
\hline
\end{tabular}

\begin{tabular}{|c|c|c|c|c|}
\hline Herfindahl-Hirschman-Index & 0 & 10000 & $S_{8}=15.81 \ln (\mathrm{HHI})-45.62$ & {$[8]$} \\
\hline $\begin{array}{l}\text { Worldwide Governance } \\
\text { Indicator - Political Stability } \\
\text { and Absence of } \\
\text { Violence/Terrorism }\end{array}$ & -2.5 & 2.5 & $S_{9}=20 *(2.5-\mathrm{WGI})$ & [9] \\
\hline Policy Perception Index & 0 & 100 & $S_{10}=100-\mathrm{PPI}$ & [10] \\
\hline Human Development Index & 0 & 1 & $S_{11}=100 * \mathrm{HDI}$ & [11] \\
\hline
\end{tabular}




\section{Country-specific elemental data tables}

Four of the supply risk indicators ("country concentration", "political stability", "policy perception", and "regulation risk") rely on country-specific production data. Tables S3, S4, S5, S6, S7 and S8 therefore show the country-specific data used in the assessment of cadmium, tellurium, copper, indium, selenium and molybdenum. Tables S9 and S10 show data used for the host metal zinc and the host mineral bauxite. Country-specific data for gallium is unavailable. The PPI is given on a regional level for USA, Australia and Canada instead of a national level, which is why regionalized mining production is necessary for these elements [10]. Withheld (W) or unavailable (n/av) production data are excluded from the calculation of country concentration and political risk scores.

Table S6: Country-specific cadmium data.

\begin{tabular}{llll} 
Country (Region) & 2014 Production $^{1}, \mathrm{t}[2]$ & WGI-PV [9] & HDI [11] \\
\hline USA & $\mathrm{W}^{2}$ & 0.62 & 0.91 \\
\hline Australia & 380 & 1.08 & 0.93 \\
\hline Bulgaria & 400 & 0.08 & 0.78 \\
\hline Canada & 1270 & 1.18 & 0.90 \\
\hline China & 7300 & -0.46 & 0.72 \\
\hline India & 450 & -0.96 & 0.59 \\
\hline Japan & 1790 & 1.02 & 0.89 \\
\hline Kazakhstan & 1200 & 0.05 & 0.76 \\
\hline Korea, Rep. of & 4090 & 0.19 & 0.89 \\
\hline Mexico & 1440 & -0.76 & 0.76 \\
\hline Netherlands & 570 & 1.05 & 0.92 \\
\hline Peru & 710 & -0.52 & 0.74 \\
\hline Poland & 400 & 0.87 & 0.83 \\
\hline Russia & 1200 & -0.84 & 0.78 \\
\hline Other ${ }^{3}$ & 1000 & 0 & 0.702
\end{tabular}

Table S7: Country-specific tellurium data.

\begin{tabular}{lccc} 
Country (Region) & 2014 Production, t [2] & WGI-PV [9] & 0.62 \\
\hline USA & $13^{4}$ & 1.18 & 0.91 \\
\hline Canada & 10 & 1.02 & 0.9 \\
\hline Japan & 45 & -0.84 & 0.78 \\
\hline Russia & 40 & 0 & 0.702
\end{tabular}

\footnotetext{
${ }^{1} 80 \%$ primary production, $20 \%$ secondary production [2]

${ }^{2} \mathrm{~W}$ : figure withheld by the data source, i.e. for reasons of confidentiality

${ }^{3}$ for "other" countries, the mean value was assumed for all country-specific indicators (WGI-PV 0, PPI 50, HDI 0.702)

${ }^{4}[17]$
} 
Table S8: Country-specific copper data.

\begin{tabular}{|c|c|c|c|c|}
\hline Country (Region) & $\begin{array}{l}2014 \text { Production, kt } \\
{[2,12,13]}\end{array}$ & WGI-PV [9] & PPI [10] & HDI [11] \\
\hline USA (Arizona) & 924 & 0.62 & 71.7 & 0.91 \\
\hline USA (New Mexico) & 81 & 0.62 & 63.2 & 0.91 \\
\hline USA (Other) & 364 & 0.62 & $50^{5}$ & 0.91 \\
\hline Australia (South Australia) & 312 & 1.08 & 76.1 & 0.93 \\
\hline Australia (Queensland) & 270 & 1.08 & 66.1 & 0.93 \\
\hline Australia (New South Wales) & 178 & 1.08 & 67 & 0.93 \\
\hline Australia (Western Territory) & 209 & 1.08 & 84.6 & 0.93 \\
\hline Australia (Tasmania) & 31 & 1.08 & 70.2 & 0.93 \\
\hline Canada (Newfoundland and Labrador) & 52 & 1.18 & 88.4 & 0.9 \\
\hline Canada (Quebec) & 42 & 1.18 & 83.6 & 0.9 \\
\hline Canada (Ontario) & 204 & 1.18 & 72.4 & 0.9 \\
\hline Canada (Manitoba) & 37 & 1.18 & 85.6 & 0.9 \\
\hline Canada (Saskatchewan) & 1 & 1.18 & 89.7 & 0.9 \\
\hline Canada (British Columbia) & 322 & 1.18 & 60.7 & 0.9 \\
\hline Canada (Yukon) & 21 & 1.18 & 70.4 & 0.9 \\
\hline Chile & 5800 & 0.49 & 72.2 & 0.82 \\
\hline China & 1620 & -0.46 & 20.7 & 0.72 \\
\hline Congo, Dem. Rep. of & 1100 & -2.27 & 27.9 & 0.34 \\
\hline Indonesia & 400 & -0.37 & 15.83 & 0.68 \\
\hline Kazakhstan & 430 & 0.05 & 42.4 & 0.76 \\
\hline Mexico & 520 & -0.76 & 52 & 0.76 \\
\hline Peru & 1400 & -0.52 & 53.9 & 0.74 \\
\hline Poland & 425 & 0.87 & 40.6 & 0.83 \\
\hline Russia & 850 & -0.84 & 30.5 & 0.78 \\
\hline Zambia & 730 & 0.21 & 52.4 & 0.56 \\
\hline Other $^{6}$ & 2400 & 0 & 50 & 0.702 \\
\hline
\end{tabular}

\footnotetext{
${ }^{5}$ some regions do not have a Policy Perception Index, in which case the mean PPI of 50 was assumed

${ }^{6}$ for "other" countries, the mean value was assumed for all country-specific indicators (WGI-PV 0, PPI 50, HDI 0.702)
} 
Table S9: Country-specific indium data.

\begin{tabular}{llll} 
Country (Region) & 2014 Production, $\mathrm{t}[2]$ & WGI-PV [9] & HDI [11] \\
\hline Belgium & 30 & 0.71 & 0.88 \\
\hline Canada & 65 & 1.18 & 0.9 \\
\hline China & 420 & -0.46 & 0.72 \\
\hline France & 48 & 0.36 & 0.88 \\
\hline Germany & 10 & 0.93 & 0.91 \\
\hline Japan & 72 & 1.02 & 0.89 \\
\hline Korea, Rep. of & 150 & 0.19 & 0.74 \\
\hline Peru & 11 & -0.52 & 0.78
\end{tabular}

Table S10: Country-specific selenium data.

\begin{tabular}{llll} 
Country (Region) & 2014 Production, t [2] & WGI-PV [9] & HDI [11] \\
\hline USA & W & 0.62 & 0.91 \\
\hline Belgium & 200 & 0.71 & 0.88 \\
\hline Canada & 150 & 1.18 & 0.9 \\
\hline Chile & 70 & 0.49 & 0.82 \\
\hline China & $\mathrm{n} / \mathrm{av}^{7}$ & -0.46 & 0.72 \\
\hline Finland & 75 & 1.28 & 0.88 \\
\hline Germany & 700 & 0.93 & 0.91 \\
\hline Japan & 760 & 1.02 & 0.89 \\
\hline Peru & 40 & -0.52 & 0.74 \\
\hline Poland & 80 & 0.87 & 0.83 \\
\hline Russia & 150 & -0.84 & 0.78 \\
\hline Other & 50 & 0 & 0.702
\end{tabular}


Table S11: Country-specific molybdenum data.

\begin{tabular}{|c|c|c|c|c|}
\hline Country (Region) & $\begin{array}{l}2014 \text { Production, } \mathrm{t} \\
{[2,13,14]}\end{array}$ & WGI-PV [9] & PPI [10] & HDI [11] \\
\hline USA (Arizona) & 20090 & 0.62 & 71.7 & 0.91 \\
\hline USA (Colorado) & 23623 & 0.62 & 71.2 & 0.91 \\
\hline USA (Idaho) & 10179 & 0.62 & 67.4 & 0.91 \\
\hline USA (Utah) & 6120 & 0.62 & 80 & 0.91 \\
\hline USA (New Mexico) & 1074 & 0.62 & 63.2 & 0.91 \\
\hline USA (Montana) & 3221 & 0.62 & 59.5 & 0.91 \\
\hline USA (Other) & 1192 & 0.62 & $50^{8}$ & 0.91 \\
\hline Armenia & 6700 & -0.21 & $50^{9}$ & 0.88 \\
\hline Canada (British Columbia) & 9500 & 1.18 & 60.7 & 0.9 \\
\hline Chile & 39000 & 0.49 & 72.2 & 0.82 \\
\hline China & 100000 & -0.46 & 20.7 & 0.72 \\
\hline Iran & 6300 & -0.91 & $50^{9}$ & 0.75 \\
\hline Kyrgyzstan & $\mathrm{n} / \mathrm{av}^{10}$ & -0.78 & 42.4 & 0.63 \\
\hline Mexico & 11000 & -0.76 & 52 & 0.76 \\
\hline Mongolia & 2000 & 0.87 & 17.1 & 0.7 \\
\hline Peru & 18100 & -0.52 & 53.9 & 0.74 \\
\hline Russia & 4800 & -0.84 & 30.5 & 0.78 \\
\hline Turkey & 2800 & -1.06 & 44.2 & 0.76 \\
\hline Uzbekistan & 550 & -0.23 & $50^{9}$ & 0.66 \\
\hline
\end{tabular}

\footnotetext{
${ }^{8}$ some regions do not have a Policy Perception Index, in which case the mean PPI of 50 was assumed

${ }^{9}$ some countries do not have a Policy Perception Index, in which case the mean PPI of 50 was assumed

${ }^{10} \mathrm{n}$ /av: not available
} 
Table S12: Country-specific zinc data.

\begin{tabular}{|c|c|c|c|c|}
\hline Country (Region) & $\begin{array}{l}2014 \text { Production, kt } \\
{[2,12,13]}\end{array}$ & WGI-PV [10] & PPI [10] & HDI [11] \\
\hline USA (Alaska) & 670 & 0.62 & 71.7 & 0.91 \\
\hline USA (Other) & 150 & 0.62 & $50^{8}$ & 0.91 \\
\hline Australia (Queensland) & 998 & 1.08 & 66.1 & 0.93 \\
\hline Australia (New South Wales) & 141 & 1.08 & 67 & 0.93 \\
\hline Australia (Western Australia) & 76 & 1.08 & 84.6 & 0.93 \\
\hline Australia (Northern Territory) & 197 & 1.08 & 69.2 & 0.93 \\
\hline Australia (Tasmania) & 87 & 1.08 & 70.2 & 0.93 \\
\hline Bolivia & 410 & -0.36 & 20.1 & 0.67 \\
\hline Canada (Newfoundland and Labrador) & 18 & 1.18 & 88.4 & 0.9 \\
\hline Canada (Quebec) & 130 & 1.18 & 83.6 & 0.9 \\
\hline Canada (Ontario) & 59 & 1.18 & 72.4 & 0.9 \\
\hline Canada (Manitoba) & 83 & 1.18 & 85.6 & 0.9 \\
\hline Canada (Saskatchewan) & 2 & 1.18 & 89.7 & 0.9 \\
\hline Canada (British Columbia) & 31 & 1.18 & 60.7 & 0.9 \\
\hline Canada (Yukon) & 28 & 1.18 & 70.4 & 0.9 \\
\hline China & 5000 & -0.49 & 20.7 & 0.72 \\
\hline India & 700 & -0.96 & 47.5 & 0.59 \\
\hline Ireland & 300 & 1.07 & 96 & 0.9 \\
\hline Kazakhstan & 330 & 0.05 & 42.4 & 0.76 \\
\hline Mexico & 700 & -0.76 & 52 & 0.76 \\
\hline Peru & 1300 & -0.52 & 53.9 & 0.74 \\
\hline Other $^{11}$ & 1900 & 0 & 50 & 0.702 \\
\hline
\end{tabular}

\footnotetext{
${ }^{11}$ for "other" countries, the mean value was assumed for all country-specific indicators (WGI-PV 0, PPI 50, HDI 0.702)
} 
Table S13: Country-specific alumina/bauxite data.

\begin{tabular}{|c|c|c|c|c|}
\hline Country (Region) & $\begin{array}{l}2014 \text { Production, } \\
\text { kt dry }[2,13]\end{array}$ & WGI-PV [10] & PPI [10] & HDI [11] \\
\hline USA & $\mathrm{n} / \mathrm{av}{ }^{12}$ & 0.62 & $50^{13}$ & 0.91 \\
\hline Canada (Queensland) & 49410 & 1.18 & 66.1 & 0.93 \\
\hline Canada (Western Australia) & 28350 & 1.18 & 84.6 & 0.93 \\
\hline Canada (Northern Territory) & 3240 & 1.18 & 69.2 & 0.93 \\
\hline Brazil & 32500 & -0.01 & 33 & 0.74 \\
\hline China & 47000 & -0.49 & 20.7 & 0.72 \\
\hline Greece & 2100 & 0.02 & 35.5 & 0.85 \\
\hline Guinea & 19300 & -0.93 & 32 & 0.56 \\
\hline Guyana & 1800 & -0.16 & 50.9 & 0.64 \\
\hline India & 19000 & -0.96 & 47.5 & 0.59 \\
\hline Indonesia & 500 & -0.37 & $50^{13}$ & 0.68 \\
\hline Jamaika & 9800 & 0.09 & $50^{13}$ & 0.72 \\
\hline Kazakhstan & 5500 & 0.05 & 42.4 & 0.76 \\
\hline Russia & 5300 & -0.84 & 30.5 & 0.78 \\
\hline Suriname & 2700 & 0.23 & $50^{13}$ & 0.71 \\
\hline Venezuela & 2200 & -0.83 & 15.4 & 0.76 \\
\hline Vietnam & 1000 & 0.00 & 26 & 0.64 \\
\hline Other $^{14}$ & 4760 & 0 & 50 & 0.702 \\
\hline
\end{tabular}

$12 \mathrm{n} / \mathrm{av}$ : not available

${ }^{13}$ some countries do not have a Policy Perception Index, in which case the mean PPI of 50 was assumed

${ }^{14}$ for "other" countries, the mean value was assumed for all country-specific indicators (WGI-PV 0, PPI 50, HDI 0.702) 


\section{Supply risk data table with notes and comments}

Many of the supply risk indicators used in our assessment rely on data from multiple sources or on assumptions. Therefore, the tables S11, S12, S13, S14 and S15 below repeat all indicator figures from the main article, alongside additional data and annotations concerning the assumptions.

Table S14: Supply risk data on elemental level.

\begin{tabular}{|c|c|c|c|c|c|c|c|}
\hline Indicator & $\mathrm{Cd}$ & $\mathrm{Te}$ & $\mathrm{Cu}$ & In & $\mathrm{Ga}$ & $\mathrm{Se}$ & Mo \\
\hline Primary production ${ }^{15}$ & $17.8 \mathrm{kt}^{16}$ & $550 t^{17}$ & $18.7 \mathrm{Mt}$ & $820 t$ & $440 t$ & $2.275 \mathrm{kt}^{18}$ & $266 \mathrm{kt}$ \\
\hline Production type & refinery & refinery & mine & refinery & refinery & refinery & mine \\
\hline $\begin{array}{l}\text { Main host metal } \\
\text { (mineral) }\end{array}$ & $\mathrm{Zn}$ & $\mathrm{Cu}$ & - & $\mathrm{Zn}$ & $\begin{array}{l}\text { Al } \\
\text { (Bauxite) }\end{array}$ & $\mathrm{Cu}$ & - \\
\hline Reserves $^{15}$ & $500 \mathrm{kt}^{19}$ & $24 \mathrm{kt}^{20}$ & $700 \mathrm{Mt}$ & $18.8 \mathrm{kt} \mathrm{[15]}$ & $1.4 \mathrm{Mt}^{21}$ & $120 \mathrm{kt}$ & $11 \mathrm{Mt}$ \\
\hline Resources $^{15}$ & $\begin{array}{l}4.75- \\
9.5 \mathrm{Mt}^{22}\end{array}$ & $192 \mathrm{kt}^{23}$ & $5.6 \mathrm{Gt}^{24}$ & 125 kt [15] & $\begin{array}{l}2.75- \\
3.75 \mathrm{Mt}^{25}\end{array}$ & $960 \mathrm{kt}^{26}$ & $19,4 \mathrm{Mt}^{27}$ \\
\hline
\end{tabular}

Table S15: Elemental data on risk of supply reduction. $\oplus$ : High figures mean high risk. $\ominus$ : Low figures mean high risk.

\begin{tabular}{lllllllllll} 
Indicator & Dimension & Risk & $\mathrm{Cd}$ & $\mathrm{Te}$ & $\mathrm{Cu}$ & $\mathrm{In}$ & $\mathrm{Ga}$ & $\mathrm{Se}$ & $\mathrm{Mo}$ \\
\hline Static Reach Reserves & years & $\ominus$ & $28 \mathrm{a}$ & $44 \mathrm{a}^{28}$ & $37 \mathrm{a}$ & $23 \mathrm{a}$ & $3182 \mathrm{a}$ & $53 \mathrm{a}$ & $41 \mathrm{a}$ \\
\hline Static Reach Resources & years & $\ominus$ & $267 \mathrm{a}^{29}$ & $349 \mathrm{a}^{28}$ & $299 \mathrm{a}$ & $152 \mathrm{a}$ & $6250 \mathrm{a}^{29}$ & $422 \mathrm{a}$ & $73 \mathrm{a}$ \\
\hline EoL-Recycling Rate [3] & $\%$ & $\ominus$ & $15 \%$ & $<1 \%$ & $43-53 \%$ & $<1 \%$ & $<1 \%$ & $<5 \%$ & $30 \%$
\end{tabular}

\footnotetext{
${ }^{15}$ estimation for 2014 unless otherwise noted [2]

${ }^{16} 80 \%$ primary production of $22.2 \mathrm{kt}$ total production (excl. USA and Italy) [2]

${ }^{17}$ lowest estimate from USGS Minerals Yearbook 2012 [23]

${ }^{18}$ excluding USA, China and other countries

${ }^{19}$ latest available figure from 2014 [24]

20 "only tellurium contained in copper reserves. These estimates assume that more than one-half of the tellurium contained in unrefined copper anodes is recoverable" [2]

${ }^{21}$ calculated from $28 \mathrm{Gt}$ bauxite reserves and a concentration of $50 \mathrm{ppm} \mathrm{Ga}$ in bauxite ore [2]

${ }^{22}$ calculated from zinc resources $(1.9 \mathrm{Gt})$ assuming a Cd:Zn-ratio of 1:400 to 1:200 [24]

${ }^{23}$ calculated from copper resources $(5.6 \mathrm{Gt})$ assuming the same Te:Cu-ratio as for reserves $(24: 700,000)$

${ }^{24}$ includes $2.1 \mathrm{Gt}$ identified and 3.5 Gt unidentified resources [25]

${ }^{25}$ calculated from bauxite resources $(55-75 \mathrm{Gt})$ and a concentration of 50ppm Ga in bauxite ore [2]

${ }^{26}$ calculated from copper resources $(5.6 \mathrm{Gt})$ assuming the same Se:Cu-ratio as for reserves $(120: 700,000)$

${ }^{27}$ identified resources in the US (5.4 Mt) and the rest of the world (14 Mt)

${ }^{28}$ assuming the lower boundary of estimated primary production volume

${ }^{29}$ assuming the lower boundary of estimated resources volume

${ }^{30}$ from both figures given in the reference, $43 \%$ recycling rate implies higher supply risk and is therefore used
} 
Table S16: Elemental data on risk of demand increase. $\oplus$ : High figures mean high risk. $\ominus$ : Low figures mean high risk.

\begin{tabular}{|c|c|c|c|c|c|c|c|c|c|}
\hline Indicator & Dimension & Risk & $\mathrm{Cd}$ & $\mathrm{Te}$ & $\mathrm{Cu}$ & In & $\mathrm{Ga}$ & Se & Mo \\
\hline $\begin{array}{l}\text { By-product } \\
\text { dependence }\end{array}$ & $\%$ & $\oplus$ & $\begin{array}{l}100 \% \\
(\mathrm{Zn})[16]\end{array}$ & $\begin{array}{l}100 \% \\
(\mathrm{Cu}, \mathrm{Pb}) \\
{[17]}\end{array}$ & $9 \%[4]$ & $\begin{array}{l}100 \% \\
(\mathrm{Zn}) \\
{[16]} \\
\end{array}$ & $\begin{array}{l}100 \% \\
\text { (Bauxite) } \\
{[16]}\end{array}$ & $\begin{array}{l}100 \% \\
(\mathrm{Cu}) \\
{[17]} \\
\end{array}$ & $\begin{array}{l}46 \% \\
(\mathrm{Cu})^{31}\end{array}$ \\
\hline $\begin{array}{l}\text { Future Technology } \\
\text { Demand }^{32}\end{array}$ & $\%$ & $\oplus$ & $\mathrm{n} / \mathrm{av}^{33}$ & $\mathrm{n} / \mathrm{av}^{33}$ & $15 \%$ & $289 \%$ & $581 \%$ & $11 \%$ & $\mathrm{n} / \mathrm{av}^{33}$ \\
\hline Substitutability ${ }^{34}$ & qualitative & $\theta$ & 62 & 62 & 30 & 40 & 62 & 53 & 30 \\
\hline
\end{tabular}

Table S17: Elemental data on concentration risk. $\oplus$ : High figures mean high risk. $\ominus:$ Low figures mean high risk.

\begin{tabular}{llllllllll} 
Indicator & Dimension & Risk & $\mathrm{Cd}$ & $\mathrm{Te}$ & $\mathrm{Cu}$ & $\mathrm{In}$ & $\mathrm{Ga}$ & $\mathrm{Se}$ & $\mathrm{Mo}$ \\
\hline Country Concentration $^{35}$ & $\mathrm{HHI}$ & $\oplus$ & $1670^{36}$ & $3338^{37}$ & $1443^{38}$ & $3159^{39}$ & $3785^{40}$ & $2268^{41}$ & $2323^{42}$ \\
\hline $\begin{array}{l}\text { Company } \\
\text { Concentration }\end{array}$ & $\mathrm{HHI}$ & $\oplus$ & $\begin{array}{l}\text { rather } \\
\text { low }\end{array}$ & $1108^{44}$ & 1108 & $1867^{45}$ & $1667^{46}$ & $1108^{47}$ & 2183 \\
& & & & & & & &
\end{tabular}

[18]

Table S18: Elemental data on political risk. $\oplus$ : High figures mean high risk. $\ominus:$ Low figures mean high risk.

\begin{tabular}{llllllllll} 
Indicator & Dimension & Risk & $\mathrm{Cd}$ & $\mathrm{Te}$ & $\mathrm{Cu}$ & $\mathrm{In}$ & $\mathrm{Ga}$ & $\mathrm{Se}$ & $\mathrm{Mo}$ \\
\hline $\begin{array}{l}\text { Political Stability } \\
\text { (WGI-PV) }\end{array}$ & qualitative & $\ominus$ & -0.24 & $0.07^{37}$ & 0.27 & -0.35 & $-0.4^{40}$ & 1.07 & -0.19 \\
\hline Policy Perception (PPI) & qualitative & $\ominus$ & $43^{50}$ & $55^{51}$ & $55^{51}$ & $43^{50}$ & $47^{52}$ & $55^{51}$ & $47^{53}$ \\
\hline Regulation Risk (HDI) $^{54}$ & qualitative & $\oplus$ & 0.79 & $0.73^{37}$ & 0.76 & 0.80 & $0.71^{40}$ & 0.88 & 0.79
\end{tabular}

\footnotetext{
31 [14] (version from 30 September 2014)

32 ratio of future technology demand by 2030 compared to annual production 2006 [6]

${ }^{33}$ cadmium, tellurium and molybdenum were not identified as key elements for future technologies with high demand tendencies [6]

${ }^{34}$ order inverted from [7] in order to represent the name in a more satisfactory way: here figure 100 means "fully substitutable", figure 0 means "not substitutable"

${ }^{35}$ [2], unless otherwise noted, other countries assumed as a single country (worst case scenario)

${ }^{36} 22.1 \mathrm{kt}$ produced in 13 countries and $1 \mathrm{kt}$ in other countries, USA and Italy not included

${ }^{37}$ only US [17] for 2008 as well as Canada, Japan and Russia for 2014

${ }^{38} 16.325 \mathrm{Mt}$ produced in 13 countries and $2.4 \mathrm{Mt}$ in other countries

${ }^{39} 819$ t produced in 9 countries

40 [16] for year 2008

${ }^{41} 2225 \mathrm{kt}$ produced in 9 countries, 50 in other countries, USA withheld, Australia, China, Iran, Kazakhstan, Philippines and Uzbekistan not included

${ }^{42} 266.25 \mathrm{kt}$ produced in 12 countries

43 [8] unless otherwise noted

${ }^{44}$ Company Concentration of tellurium applies to copper

${ }^{45}$ Top 3: 56\%, Asian Metals (2007) [26]

${ }^{46}$ Top 3: 50\%, [26]

${ }^{47}$ Company Concentration of selenium applies to copper

${ }^{48}$ Production shares 2014 from [2] unless otherwise noted, WGI-PV values 2013 from [9]

${ }^{49}$ Production shares 2014 from [2] unless otherwise noted, PPI values 2014 from [10], PPI values apply to host metal production countries, which is zinc for cadmium and indium, copper for tellurium and selenium, and bauxite for gallium.

${ }^{50}$ Zinc production: US state production for year 2012 [23], Australian state/territory production for year 2012 [12], Canadian province/territory production for year 2014 [13]

${ }^{51}$ Copper production: US state production for year 2011 [23], Australian state/territory production for year 2012 [12], Canadian province/territory production for year 2014 [13]

${ }_{52}$ Australian state/territory production from distribution of assessable economic demonstrated resources [12].

${ }^{53}$ Molybdenum mining production: US state production for year 2013 [14], Canadian province/territory production for year 2014 [13]

${ }^{54}$ Production shares 2014 from [2] unless otherwise noted, HDI values 2013 from [11]
} 
Table S19: Normalized elemental supply risk scores in all eleven indicators. High figures mean high risk.

\begin{tabular}{llllllll} 
Indicator & Cd & Te & Cu & In & Ga & Se & Mo \\
\hline Static Reach Reserves & 88 & 76 & 81 & 91 & 0 & 67 & 78 \\
\hline Static Reach Resources & 0 & 0 & 0 & 38 & 0 & 0 & 82 \\
\hline EoL-Recycling Rate & 85 & 99 & 57 & 99 & 99 & 95 & 70 \\
\hline By-product dependence & 100 & 100 & 9 & 100 & 100 & 100 & 46 \\
\hline Future Technology Demand & 6 & 14 & 6 & 58 & 83 & 4 & 26 \\
\hline Substitutability & 38 & 38 & 70 & 60 & 38 & 47 & 70 \\
\hline Country Concentration & 61 & 76 & 58 & 75 & 79 & 68 & 68 \\
\hline Company Concentration & 0 & 65 & 65 & 73 & 72 & 65 & 76 \\
\hline Political Stability & 51 & 49 & 49 & 50 & 58 & 34 & 50 \\
\hline Policy Perception & 57 & 45 & 45 & 57 & 53 & 45 & 53 \\
\hline Regulation Risk & 79 & 73 & 76 & 80 & 71 & 88 & 79
\end{tabular}




\section{Expert questionnaire for supply risk indicator weighting}

Expert questionnaire to evaluate the supply risks of raw materials for thin-film photovoltaic technologies

\section{The goal of this questionnaire}

Using an appropriate evaluation model we are planning to assess the relative supply risks associated with the thinfilm photovoltaic technologies CdTe and CIGS. The aim of the questionnaire is to put this exercise on a broader basis by involving experts in the field.

Four risk categories are considered: (1) risk of supply reduction, (2) risk of demand increase, (3) risk of concentration in a few hands and (4) political risk. Each category consists of two or three indicators, making eleven in total. The weighting of each indicator is not pre-determined. Your expertise will contribute to this part of the assessment. A brief explanation of the indicators can be found on pages 4 and 5 .

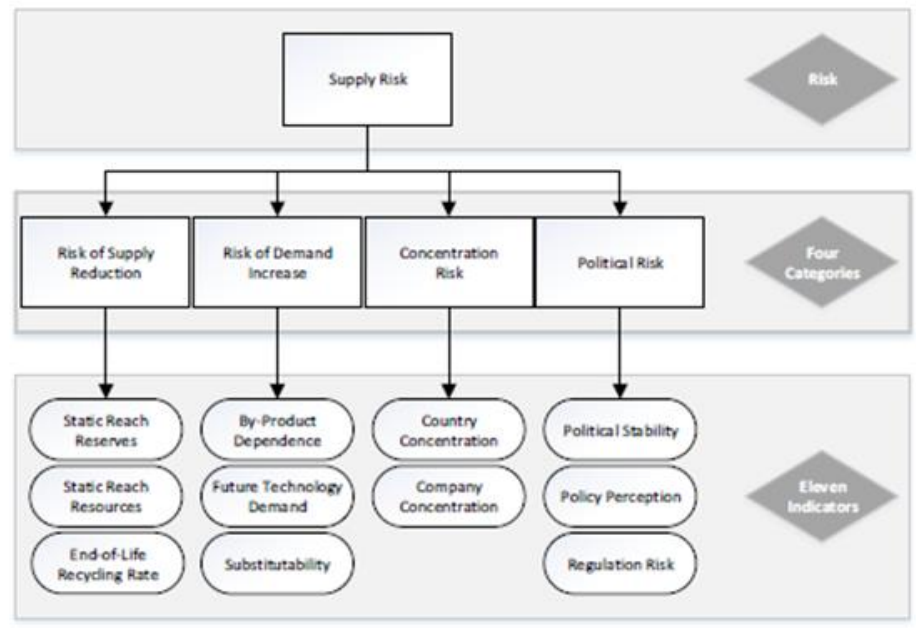

Figure 1: Evaluation model showing the eleven supply risk indicators in four categories

You have two tasks in this questionnaire: Your first task is the pairwise comparison of the overall importance of the four supply risk categories (see table 1 on page 2). This will determine the weighting of the categories.

Your second task is the pairwise comparison of the importance of the indicators within each of the four categories (see tables 2 to 5 on page 2). These comparisons determine the local weighting of the indicators within each category. We will then calculate the global weighting of the eleven supply risk indicators. Please note that we are asking you about the general importance of these supply risk aspects in the context of thin-film photovoltaics; we are not asking whether or not the supply risk aspects are already an issue for these materials.

An example of the procedure for the pairwise comparison of three indicators, which also serves for the pairwise comparison of categories, can be seen on page 3 . On pages 4 and 5 , you can find a short explanation of the indicators and their interpretation for raw material supply risks.

For both tasks in the questionnaire, an evaluation scale from 1 to 9 is used for the pairwise comparisons:

- 1 (both indicators/categories are equally important)

- 9 (one indicator/category is extremely dominant) 
Expert questionnaire to evaluate the supply risks of raw materials for thin-film photovoltaic technologies Please use the following rating scale:

\begin{tabular}{|c|c|c|c|c|c|c|c|c|c|c|c|c|c|c|c|c|}
\hline 9 & 8 & 7 & 6 & 5 & 4 & 3 & 2 & 1 & 2 & 3 & 4 & 5 & 6 & 7 & 8 & 9 \\
\hline हू & 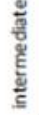 & 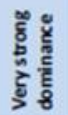 & 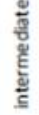 & 炎 &  &  &  & 营 & $\begin{array}{l}\text { हैँ } \\
\text { है } \\
\text { है } \\
\text { है }\end{array}$ & 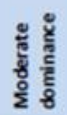 & 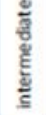 & 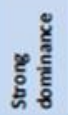 & $\begin{array}{l}\frac{3}{8} \\
\frac{8}{8} \\
\text { है } \\
\text { gू }\end{array}$ & 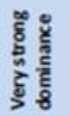 & $\begin{array}{l}\text { है } \\
\text { है } \\
\text { है } \\
\text { है }\end{array}$ & हूँ \\
\hline
\end{tabular}

\section{Questionnaire task 1: Deciding the weighting of each category}

Please fill in your individual evaluation of the categories here.

Please make sure to fill each line with a cross for the evaluation, but only use a single cross for each line.

Table 1: Pairwise comparison of the four categories overall

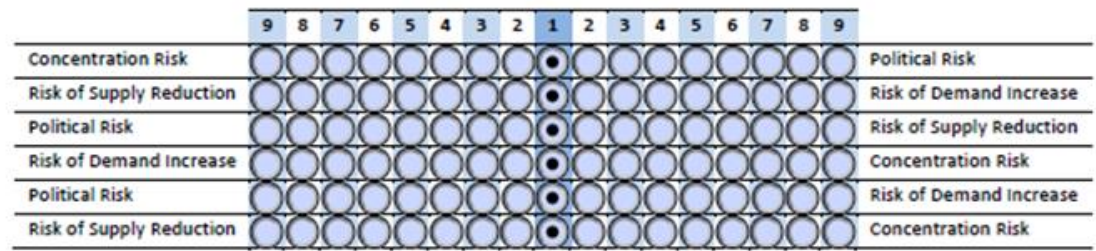

\section{Questionnaire task 2: Deciding the weighting of each indicator}

Table 2: Pairwise comparison of the three indicators in the category Risk of Supply Reduction

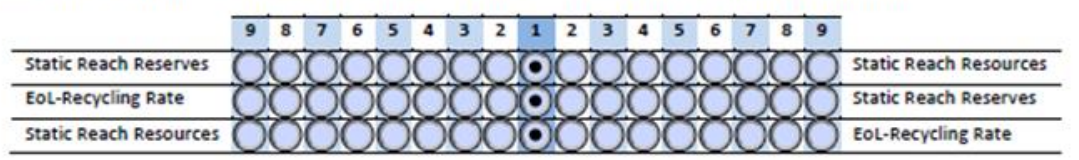

Table 3: Pairwise comparison of the three indicators in the category Risk of Demand Increase

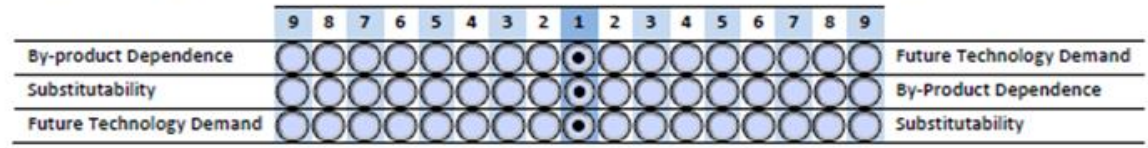

Table 4: Pairwise comparison of the two indicators in the category Concentration Risk

\begin{tabular}{|c|c|c|c|c|c|c|c|c|c|c|c|c|c|c|c|c|}
\hline & & & & & & & & & & & & & & & & \\
\hline & 98 & 7 & 6 & 5 & 4 & 3 & 2 & 1 & 2 & 3 & 45 & $\begin{array}{ll}5 & 6\end{array}$ & 7 & 8 & 9 & \\
\hline country concentration & & & & & & & & ๑) & & & & & & & & Company concentration \\
\hline
\end{tabular}

Table 5: Pairwise comparison of the three indicators in the category Political Risk

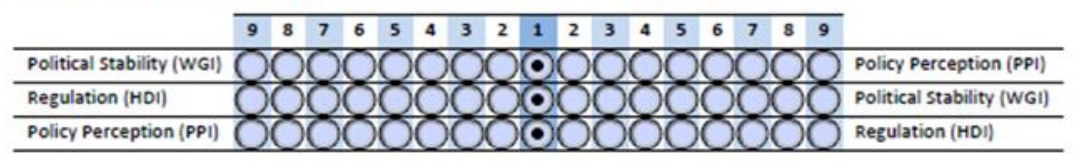

Many thanks for your time and for putting your expertise at our disposal! Page 2 of 5

Figure S8: Questionnaire for AHP, part 2 
Expert questionnaire to evaluate the supply risks of raw materials for thin-film photovoltaic technologies

Example for the pairwise comparison of the importance of indicators

Please use the following rating scale:

\begin{tabular}{|c|c|c|c|c|c|c|c|c|c|c|c|c|c|c|c|c|}
\hline 9 & 8 & 7 & 6 & 5 & 4 & 3 & 2 & 1 & 2 & 3 & 4 & 5 & 6 & 7 & 8 & 9 \\
\hline 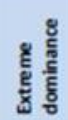 &  & 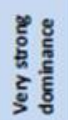 & 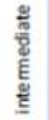 & 总 & 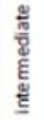 & 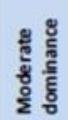 & $\begin{array}{l}\frac{2}{N} \\
\frac{\pi}{8} \\
\text { हू } \\
\text { हूँ }\end{array}$ & 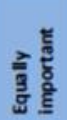 & 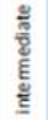 & 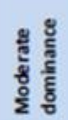 & 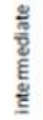 & 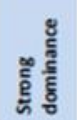 & 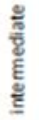 &  & 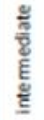 & $\begin{array}{l}\text { \& } \\
\text { है } \\
\text { है } \\
\frac{5}{6} \\
\text { है }\end{array}$ \\
\hline
\end{tabular}

In order to make a pairwise comparison of three indicators (A, B and C) three comparisons are required:

$$
\begin{array}{ll}
1^{\text {tt }} \text { comparison: } & \text { the relative importance of indicators } A \text { and } B \text {, using the above rating scale } \\
2^{\text {no }} \text { comparison: } & \text { the relative importance of indicators } C \text { and } A \text {, using the above rating scale } \\
3^{\text {rd }} \text { comparison: } & \text { the relative importance of indicators } B \text { and } C \text {, using the above rating scale }
\end{array}
$$

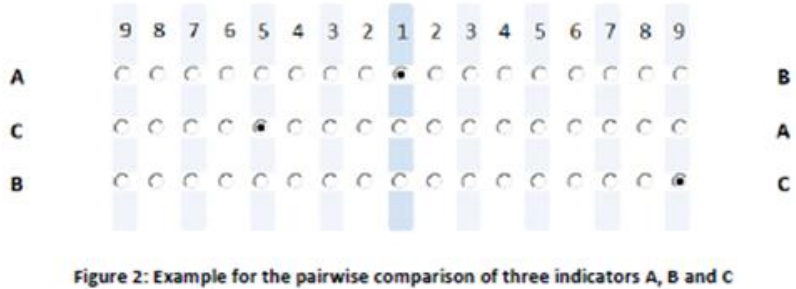

In the first pairwise comparison, the two indicators $A$ and $B$ are judged to be equally important (value 1 on the scale), i.e. indicators $A$ and $B$ are weighted with a ratio of 1 to 1.

In the second pairwise comparison, the indicator $\mathrm{C}$ is assessed to have a strong dominance over indicator $\mathrm{A}$ (value 5 on the scale on the side of indicator $\mathrm{C}$ ), i.e. the indicators $\mathrm{C}$ and $\mathrm{A}$ are weighted with a ratio of 5 to 1 .

In the third pairwise comparison, the indicator $\mathrm{C}$ is assessed to have an extreme dominance over indicator $\mathbf{B}$ (value 9 on the scale on the side of indicator $\mathrm{C}$ ), i.e. the indicators $\mathrm{C}$ and $\mathrm{B}$ are weighted with a ratio of 9 to 1 .

Combining the three pairwise comparisons via a mathematical evaluation, the resulting relative weighting of the three indicators is:

$$
A: B: C=12.7 \%: 10.4 \%: 76.9 \%
$$

Page 3 of 5

Figure S9: Questionnaire for AHP, part 3

Pages 4 and 5 of the questionnaire are identical with pages S2 and S3 of this Supplementary Material. 
Table S20: AHP matrix for categories of supply risk.

\begin{tabular}{llllll}
$\mathrm{CR}^{55}: 0.004$ & Supply Reduction & Demand Increase & Concentration & Political Risk & Local Weight \\
\hline Supply Reduction & 1 & 0.71 & 0.57 & 1.12 & 0.20 \\
\hline Demand Increase & 1.41 & 1 & 0.94 & 1.60 & 0.29 \\
\hline Concentration & 1.76 & 1.06 & 1 & 1.43 & 0.31 \\
\hline Political Risk & 0.90 & 0.63 & 0.70 & 1 & 0.19
\end{tabular}

Table S21: AHP matrix for risks of supply reduction.

\begin{tabular}{llllll}
$\mathrm{CR}^{55}: 0.060$ & Static Reach & Resource Reach & EoL-RR & Local Weight & Global Weight \\
\hline Static Reach & 1 & 2.12 & 0.55 & 0.33 & 0.066 \\
\hline Resource Reach & 0.47 & 1 & 0.55 & 0.20 & 0.040 \\
\hline EoL-RR & 1.82 & 1.83 & 1 & 0.47 & 0.093
\end{tabular}

Table S22: AHP matrix for risks of demand increase.

\begin{tabular}{llllll}
$\mathrm{CR}^{55}: 0.007$ & By-Product & Future Demand & Substitutability & Local Weight & Global Weight \\
\hline By-Product & 1 & 0.82 & 0.79 & 0.29 & 0.084 \\
\hline Future Demand & 1.22 & 1 & 1.27 & 0.38 & 0.112 \\
\hline Substitutability & 1.26 & 0.79 & 1 & 0.33 & 0.097
\end{tabular}

Table S23: AHP matrix for concentration risks.

\begin{tabular}{lllll}
$\mathrm{CR}^{55}: 0.000$ & Static Reach & Resource Reach & Local Weight & Global Weight \\
\hline Static Reach & 1 & 2.34 & 0.70 & 0.219 \\
\hline Resource Reach & 0.43 & 1 & 0.30 & 0.094
\end{tabular}

Table S24: AHP matrix for policy risks.

\begin{tabular}{llllll}
$\mathrm{CR}^{55}: 0.001$ & WGI-PV & PPI & HDI & Local Weight & Global Weight \\
\hline WGI-PV & 1 & 1.47 & 1.24 & 0.40 & 0.078 \\
\hline $\mathrm{PPI}$ & 0.68 & 1 & 0.93 & 0.28 & 0.055 \\
\hline $\mathrm{HDI}$ & 0.81 & 1.07 & 1 & 0.31 & 0.061
\end{tabular}

\footnotetext{
${ }^{55} \mathrm{CR}$ : consistency ratio, which needs to be below 0.1 for each comparison table.
} 


\section{Supply risk aggregation for CdTe and CIGS}

Figure S4 displays all indicator values (points) for the supply risk assessment on an elemental level, similar to figure 3 in the article. The bars are the resulting supply risk scores on the elemental level after aggregation of the indicators with AHP-determined weightings.

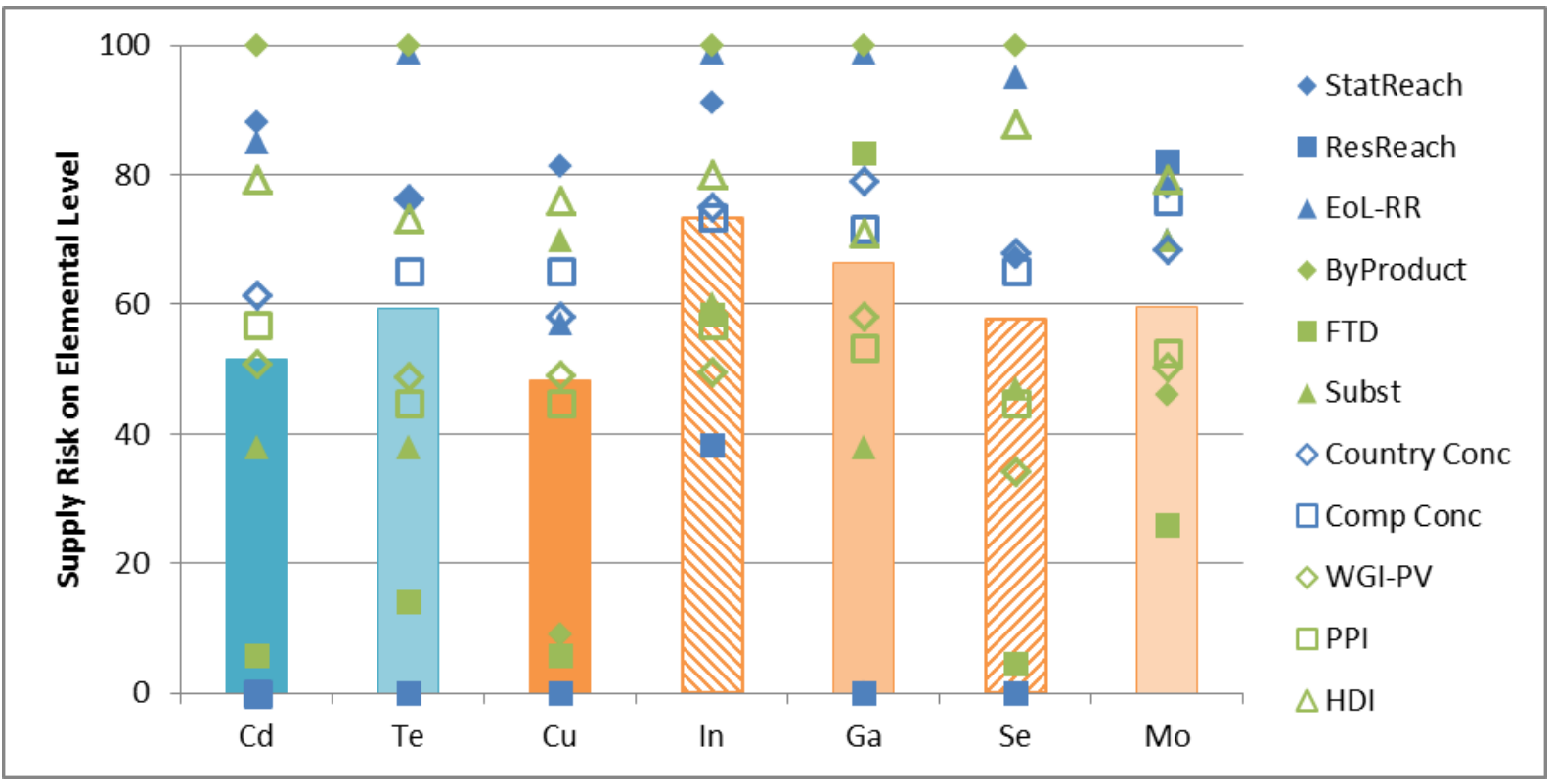

Figure S10: Elemental supply risks after aggregation of all indicators to a single value, following the AHPdetermined weightings.

Mass shares of each element in each technology and the commodity prices of each material and the resulting weight of each element in the "mass share" and "cost share" aggregation methods are displayed in table S22 (for CdTe) and table S23 (for CIGS).

Table S25: Material intensity data and commodity price data for CdTe cells.

\begin{tabular}{lll} 
Data & $\mathrm{Cd}$ & Te \\
\hline Mass, kg/MWp & $153.4[19]$ & $137.7[19]$ \\
\hline Mass share, \% & 52.7 & 47.3 \\
\hline Specific material costs, USD/kg & & $77.5^{58}$ \\
\hline Raw material costs, USD/MWp & $0.86^{57}$ & 10672 \\
\hline Cost share, \% & 131.92 & 98.8
\end{tabular}

\footnotetext{
${ }^{56}$ commodity prices as of August 2015 [27]

${ }^{57}$ Cadmium, MB free market, min. $99.95 \%$, in warehouse

${ }^{58}$ Tellurium, min. 99.99\%, Europe
} 
Table S26: Material intensity and commodity price data for CIGS cells.

\begin{tabular}{llllll} 
Data & $\mathrm{Cu}$ & $\mathrm{In}$ & $\mathrm{Ga}$ & $\mathrm{Se}$ & Mo \\
\hline Mass, kg/MWp & $21.0[20]$ & $19.0[20]$ & $2.3[20]$ & $9.6[20]$ & $90.0[21]$ \\
\hline Mass share, \% & 14.8 & 13.4 & 1.6 & 6.7 & 63.4 \\
\hline Specific material costs, USD/kg & $5.089^{59}$ & $315.63^{60}$ & $144.4^{61}$ & $24.11^{62}$ & $12.86^{63}$ \\
\hline Raw material costs, USD/MWp & 106.97 & 5993.8 & 337.9 & 230.49 & 1157.4 \\
\hline Cost share, \% & 1.4 & 76.6 & 4.3 & 2.9 & 14.8
\end{tabular}

${ }^{59}$ Copper, grade A, LME, cash, in LME warehouse

${ }^{60}$ Indium, ingots, min. 99.97\%, free market, in warehouse

${ }^{61}$ Gallium, min. $99.99 \%$ fob China

${ }^{62}$ Selenium, min. 99.5\%, free market, in warehouse

${ }^{63}$ Molybdenum, oxide, drummed, Europe, free market, in warehouse, price per kg Mo 


\section{Sensitivity analysis: Alternative weightings}

To illustrate the sensitivity of the results to the indicator weighting within the Analytic Hierarchy Process (AHP), we calculate the supply risks on the element-level and technology levels for two alternative (simple) weighting possibilities and compare them with the results of our assessment. Table S24 lists the weighting of each indicator for the AHP case as well as for the two alternatives "group weighting" and "equal weighting". Figure S5 illustrates the results obtained from our assessments in comparison with the two alternative weightings. For six out of seven elements $(\mathrm{Cd}$, $\mathrm{Te}, \mathrm{Cu}, \mathrm{In}, \mathrm{Ga}$ and $\mathrm{Se}$ ), the AHP weightings gives the highest supply risk value. Only for molybdenum the opposite is true: Group weighting and equal weighting would result in a higher supply risk value than for the AHP case. The largest change in supply risk values occurs for gallium (more than 5 supply risk points extra in the AHP weighting). Overall, the sequence of elements (if sorted by supply risk) does not change between the three weightings.

Table 27: Alternatives to the weightings determined by the Analytic Hierarchy Process: "Group weighting" weights all risk categories equally (weighting depends on number of indicators in each risk category), "equal weighting" weights all eleven indicators equally.

\begin{tabular}{|c|c|c|c|c|}
\hline Category & Indicator & AHP weighting & Group weighting & Equal weighting \\
\hline \multirow[t]{3}{*}{ Risk of Supply Reduction } & Static Reach Reserves & $6.6 \%$ & $8.3 \%$ & $9.2 \%$ \\
\hline & Static Reach Resources & $4.0 \%$ & $8.3 \%$ & $9.2 \%$ \\
\hline & End-of-Life Recycling Rate & $9.3 \%$ & $8.3 \%$ & $9.2 \%$ \\
\hline \multirow[t]{3}{*}{ Risk of Demand Increase } & By-Product Dependence & $8.4 \%$ & $8.3 \%$ & $9.2 \%$ \\
\hline & Future Technology Demand & $11.2 \%$ & $8.3 \%$ & $9.2 \%$ \\
\hline & Substitutability & $9.7 \%$ & $8.3 \%$ & $9.2 \%$ \\
\hline \multirow[t]{2}{*}{ Concentration Risk } & Country Concentration & $21.9 \%$ & $12.5 \%$ & $9.2 \%$ \\
\hline & Company Concentration & $9.4 \%$ & $12.5 \%$ & $9.2 \%$ \\
\hline \multirow[t]{3}{*}{ Policy Risk } & Political Stability & $7.8 \%$ & $8.3 \%$ & $9.2 \%$ \\
\hline & Policy Perception & $5.5 \%$ & $8.3 \%$ & $9.2 \%$ \\
\hline & Regulation & $6.1 \%$ & $8.3 \%$ & $9.2 \%$ \\
\hline
\end{tabular}




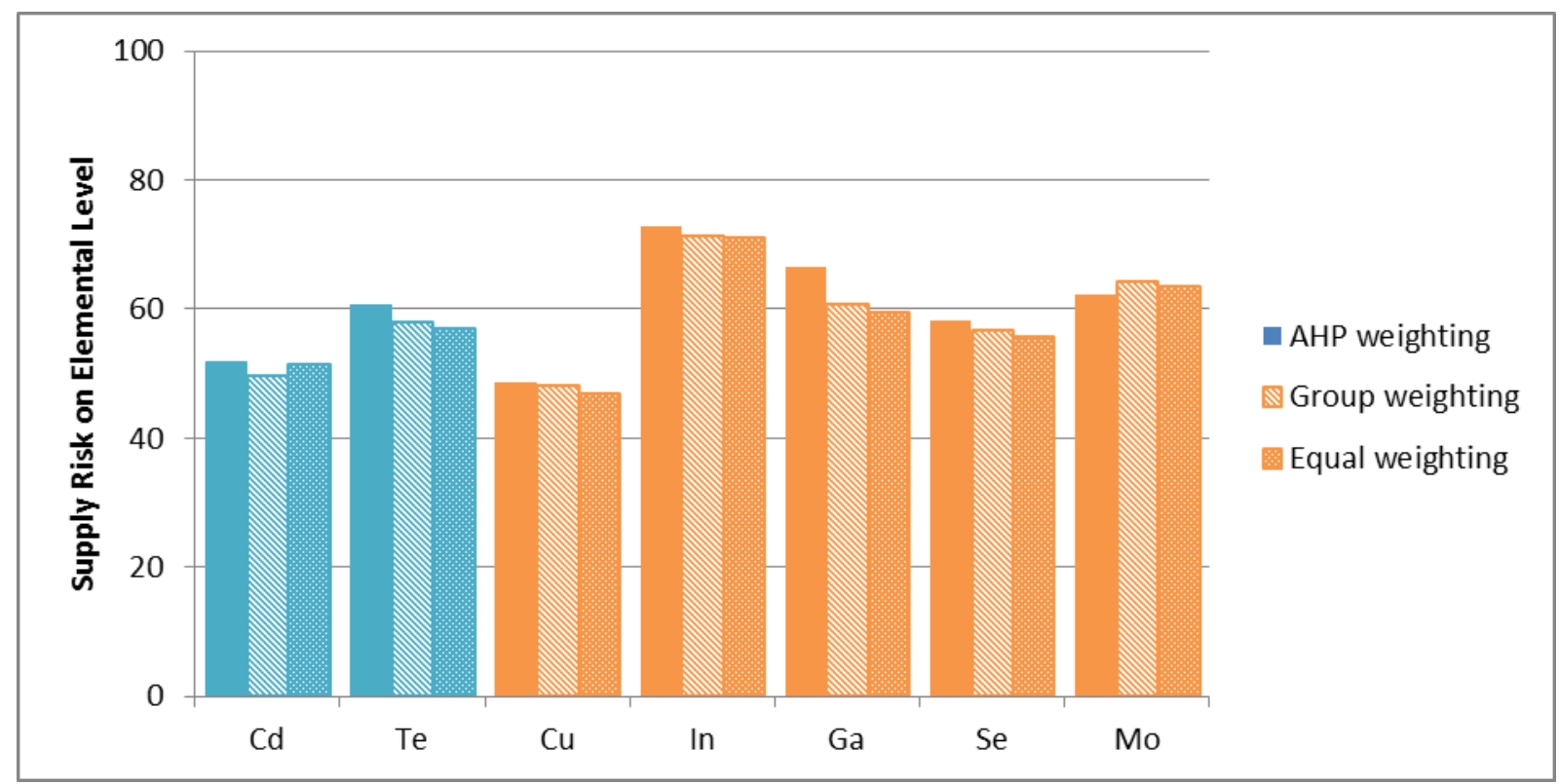

Figure S11: Supply risk on the elemental level" for different weighting scenarios: AHP weighting uses indicator weightings as presented in the main article; "group weighting" uses equal weightings for all risk categories; "equal weighting" uses equal weightings for all eleven indicators.

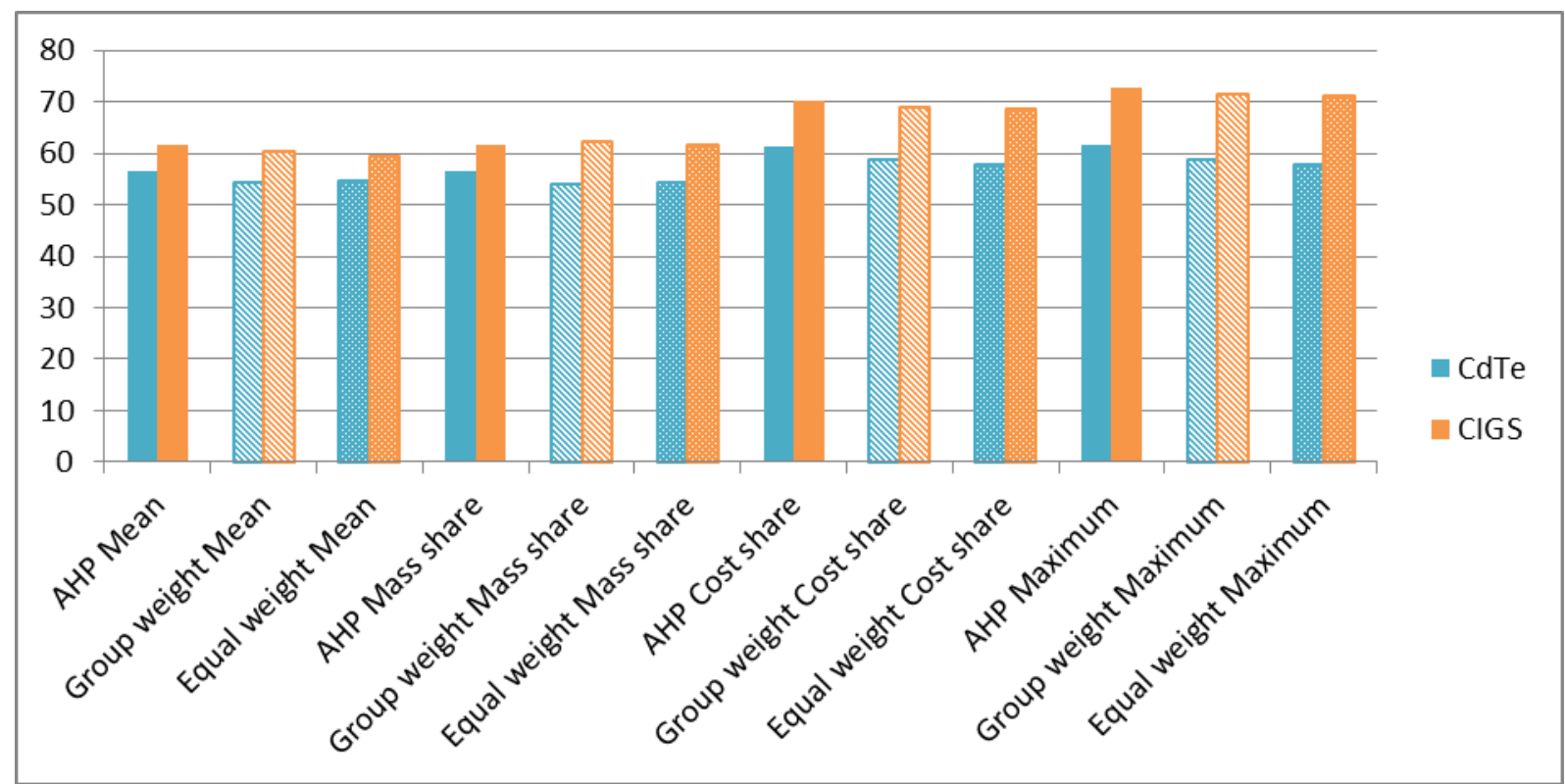

Figure S12: Supply risk on the technology level for different weighting and aggregation scenarios. Individual element results: see figure S5. "AHP weighting" uses indicator weightings as presented in the main article; "group weighting" uses equal weightings for all risk categories; "equal weighting" uses equal weightings for all eleven indicators. Arithmetic "mean": each element has same weighting. "Mass-share" aggregation: elements are weighted according to their mass share in the photovoltaic layer. "Cost-share" aggregation: elements are weighted according to their raw material cost share. "Maximum" weighting: the element with the highest supply risk determines the supply risk for the technology. 


\section{Monte Carlo simulation for uncertainty analysis}

In order to test the results of our assessment with respect to data gaps and uncertainties, we have performed a Monte Carlo simulation. Raw data were given an assumed distribution (lognormal, normal, triangular or equal) and 10000 sequences with software-generated random numbers according to these distributions were used to calculate resulting distributions of the elemental and technology supply risk scores. Lognormal distributions were used mostly for physical values from literature (production volumes, reserves and resources, future technology demand, company concentration). Triangular distributions were used for data with a per-definition minimum and maximum value (e.g., 0 to 100). Normal distributions were given for Worldwide Governance Indicator values. Equal distributions were used if the PPI score of a country was unknown. PPI scores and HDI scores are the results of estimates made by others and are not explicitly modelled with uncertainties (but each production share of a country has a simulated distribution). Table S25 gives a list for all quantitative uncertainty distributions for raw data. The resulting box plot graph is given illustrated in the manuscript as Figure 6.

Table S28: Assumptions for the distributions required for Monte Carlo (MC) simulation

\begin{tabular}{|c|c|c|}
\hline Data point & Distribution for MC simulation & Standard deviation $[1,9,22]$ \\
\hline Production volume (country-specific) & Lognormal & $\mathrm{GSD}^{2}=1.228^{64}$ \\
\hline Reserves (global) & Lognormal & $\mathrm{GSD}^{2}=1.237$ \\
\hline Resources (global) & Lognormal & $\mathrm{GSD}^{2}=1.237$ \\
\hline EoL-Recycling Rate & Triangular & Min: 0\%, Max: 100\%, Mean: given \\
\hline By-Product Dependence & Triangular & Min: 0\%, Max: 100\%, Mean: given \\
\hline Future Technology Demand & Lognormal & $\mathrm{GSD}^{2}=1.228$ \\
\hline Substitutability & Triangular & Min: 0, Max: 100, Mean: given \\
\hline Country Concentration & $\begin{array}{l}\text { calculated from country-specific } \\
\text { production volumes }\end{array}$ & - \\
\hline Company Concentration & Lognormal & $\mathrm{GSD}^{2}=1.228$ \\
\hline WGI-PV (country-specific) & Normal & taken from data source \\
\hline PPI (country-specific) & $\begin{array}{l}\text { PPI available: no data uncertainty } \\
\text { assumed } \\
\text { PPI unavailable: equal distribution }\end{array}$ & -; Min: 0, Max: 100 \\
\hline HDI (country-specific) & no data uncertainty assumed & - \\
\hline Mass, kg/MWp & Lognormal, Triangular & $\begin{array}{l}\text { GSD }^{2}=1.228 \\
\text { Cd-Min: } 140.1 \text {, Cd-Max: } 166.6 \\
\text { Te-Min: } 93.3 \text {, Te-Max: } 182.0\end{array}$ \\
\hline Commodity price & Lognormal & $\mathrm{GSD}^{2}=1.237$ \\
\hline
\end{tabular}

\footnotetext{
${ }^{64} \mathrm{GSD}^{2}$ : squared geometric standard deviation
} 


\section{References}

[1] Graedel TE, Barr R, Chandler C, Chase T, Choi J, Christoffersen L, et al. Methodology of Metal Criticality Determination. Environ Sci Technol 2012;46:1063-70. doi:10.1021/es203534z.

[2] USGS. Mineral Commodity Summaries 2015. U.S. Geological Survey; 2015.

[3] Graedel TE, Allwood J, Birat J-P, Reck BK, Sibley SF, Sonnemann G, et al. Recycling Rates of Metals - A Status Report, A Report of the Working Group on the Global Metal Flows to the International Resource Panel. UNEP; 2011.

[4] Nassar NT, Graedel TE, Harper EM. By-product metals are technologically essential but have problematic supply. Sci Adv 2015;1:e1400180. doi:10.1126/sciadv.1400180.

[5] Schneider L, Berger M, Schüler-Hainsch E, Knöfel S, Ruhland K, Mosig J, et al. The economic resource scarcity potential (ESP) for evaluating resource use based on life cycle assessment. Int J Life Cycle Assess 2014;19:601-10. doi:10.1007/s11367-013-0666-1.

[6] Angerer G, Marscheider-Weidemann F, Lüllmann A, Erdmann L, Scharp M, Handke V, et al. Raw Materials for Emerging Technologies. Stuttgart: Frauenhofer IRB Verlag; 2009.

[7] Graedel TE, Harper EM, Nassar NT, Reck BK. On the materials basis of modern society. Proc Natl Acad Sci 2015;112:6295-300. doi:10.1073/pnas.1312752110.

[8] Buchholz P, Huy D, Liedtke M, Schmidt M. DERA-Rohstoffliste 2014. 2015.

[9] Kaufmann D, Kraay A. Worldwide Governance Indicators 2015. http://info.worldbank.org/ governance/wgi/index.aspx\#home (accessed December 1, 2015).

[10] Jackson T, Green KP. Fraser Institute Annual Survey of Mining Companies, 2014. 2015.

[11] UNDP. Human Development Report 2014. 2014.

[12] Geoscience Australia. Australia's Identified Mineral Resources 2013. Canberra: 2013.

[13] Natural Resources Canada. Preliminary estimate of the mineral production of Canada, by province, 2014 2015. http://sead.nrcan.gc.ca/prod-prod/2014p-eng.aspx (accessed March 25, 2015).

[14] SNL Metals \& Mining. Raw Materials Data. Version 20. Sweden: 2014.

[15] Schwarz-Schampera U. Indium. In: Gunn G, editor. Crit. Met. Handb., John Wiley \& Sons; 2014, p. 204-29.

[16] Harper EM, Kavlak G, Burmeister L, Eckelman MJ, Erbis S, Sebastian Espinoza V, et al. Criticality of the Geological Zinc, Tin, and Lead Family. J Ind Ecol 2015;19:628-44. doi:10.1111/jiec.12213.

[17] Nassar NT, Barr R, Browning M, Diao Z, Friedlander E, Harper EM, et al. Criticality of the geological copper family. Environ Sci Technol 2012;46:1071-8. doi:10.1021/es203535w.

[18] Pfleger P, Lichtblau K, Bardt H, Bertenrath R. Rohstoffsituation der bayerischen Wirtschaft. München: 2015.

[19] Zimmermann T, Gößling-Reisemann S. Recycling Potentials of Critical Metals-Analyzing Secondary Flows from Selected Applications. Resources 2014;3:291-318. doi:10.3390/ resources3010291.

[20] Moss RL, Tzimas E, Kara H, Willis P, Kooroshy J. Critical Metals in Strategic Energy Technologies. Luxembourg: European Commission; 2011.

[21] Schriefl E, Bruckner M, Haider A, Windhaber M. Metallbedarf von Erneuerbare-EnergieTechnologien. Wien: energieautark consulting GmbH, SERI; 2013.

[22] Goedkoop A.; Oele, M.; Sipke, D.; de Roest, D. M. DS, Goedkoop M, De Schryver A, Oele M, Sipke D, de Roest D. Introduction to LCA with SimaPro 7. PRé Consultants; 2007.

[23] USGS. Minerals Yearbook 2012: Volume I - Metals and Minerals. 2013. 
[24] USGS. Mineral commodity summaries 2014. 2014.

[25] Johnson KM, Hammarstrom JM, Zientek ML, Dicken CL. Estimate of Undiscovered Copper Resources of the World, 2013. 2014.

[26] Erdmann L, Behrendt S, Feil M. Kritische Rohstoffe für Deutschland. Berlin: KfW Bankengruppe; 2011.

[27] DERA. DERA Preismonitor August 2015. 2015. 